Board of Governors of the Federal Reserve System

International Finance Discussion Papers

Number 669

June 2000

\title{
THE IMPACT OF MONETARY POLICY ON EXCHANGE RATES DURING FINANCIAL CRISES
}

David M. Gould and Steven B. Kamin

NOTE: International Finance Discussion Papers are preliminary materials circulated to stimulate discussion and critical comment. References to International Finance Discussion Papers (other than an acknowledgement that the writer has had access to unpublished material) should be cleared with the author or authors. Recent IFDPs are available on the Web at www.bog.fed.us. 


\title{
THE IMPACT OF MONETARY POLICY ON EXCHANGE RATES DURING FINANCIAL CRISES
}

\author{
David M. Gould and Steven B. Kamin*
}

June 2000

\begin{abstract}
This paper addresses the impact of monetary policy on exchange rates during financial crises. Some observers have argued that a tightening of monetary policy is necessary to stabilize the exchange rate, restore confidence, and lay the groundwork for an eventual recovery of economic activity. Others have argued that raising interest rates, by reducing the ability of borrowers to repay loans and thereby weakening the banking system, may further reduce investor confidence and lead to further weakening-not strengthening-of domestic currencies.

This debate, which became highly charged during the Asian financial crisis, remains unresolved. A key reason is that, because of the endogeneity of interest rates with respect to exchange rates and investor expectations, it is difficult to use statistical analysis to identify the impact of monetary policy on the exchange rate. In our research, we use measures of international credit spreads and of domestic stock prices as proxies for investor concerns about creditworthiness and country risk in order to better identify the impact of monetary policies on the exchange rate. Using weekly data from Indonesia, Korea, Malaysia, the Philippines, Thailand, and Mexico, we find that credit spreads and stock prices exert significant impacts on exchange rates during financial crises, but interest rates still are not estimated to have significant effects. We conclude that while monetary policy probably does exert an important influence over exchange rates, this most likely takes place slowly, as central banks attempt to establish credibility, and over longer periods of time than can be captured in our analysis.
\end{abstract}

Keywords: exchange rates, interest rates, financial crises

* The authors are Senior Economist, Institute of International Finance (dgould@iif.com), and Assistant Director, International Finance Division, Federal Reserve Board of Governors (steven.kamin@frb.gov). This paper was written while David Gould was a Senior Economist and Policy Advisor at the Federal Reserve Bank of Dallas. It was prepared as a chapter in a forthcoming edited volume, Reuven Glick, Ramon Moreno, and Mark Spiegel, eds., Financial Crises in Emerging Markets, Cambridge University Press. Justin May and Trevor Dinmore provided superb research assistance. The views in this paper are solely the responsibility of the authors and should not be interpreted as reflecting the views of the Board of Governors of the Federal Reserve System, the Institute of International Finance, or of any other person associated with the Federal Reserve System or the Institute of International Finance. We are indebted to Pierre-Richard Agenor, Henning Bohn, Reuven Glick, Ramon Moreno, Mark Spiegel, and other participants of the FRBSF Conference on Financial Crises in Emerging Markets for helpful comments. 


\subsection{INTRODUCTION}

One of the most controversial issues that has emerged in the aftermath of the Asian financial crisis has been the appropriate response of monetary policy. Following the abandonment of exchange rate pegs, currencies depreciated rapidly in Thailand, Malaysia, Indonesia, Korea, and the Philippines. These depreciations appeared to be very adverse in their consequences, leading not only to somewhat higher inflation but also to banking sector distress and economic recession as falling currencies led to balance-sheet effects that exacerbated already existing financial sector problems. In consequence, some observers-and notably the IMF-have argued that a significant tightening of monetary policy was necessary in order to stabilize the exchange rate, restore confidence, and lay the groundwork for an eventual recovery of economic activity. Conversely, a substantial number of other economists contend that when balance-ofpayments crises occur simultaneously with financial sector crises, as was the case in Asia, a tightening of monetary policy may be counter-productive. These "revisionists" argue that raising interest rates may further reduce investor confidence and lead to further weakening —not strengthening —of domestic currencies by reducing the ability of borrowers to repay loans and thereby weakening the banking system.

Roughly two years after the Asian financial crisis started, this debate remains unresolved. A key reason for this is that it is extremely difficult to use historical experience to identify the impact of monetary policy on the exchange rate. Generally, monetary authorities tighten policy during periods of strong downward pressure on the exchange rate and loosen policy as this pressure is alleviated. During the Asian financial crisis, collapses in currency values were associated with rising interest rates. Subsequently, exchange rate appreciations have been associated with falling interest rates. Although, at face value, it would seem that raising interest 
rates during the Asian crisis had the counter-intuitive effect of depreciating the exchange rate, it would be inappropriate to place significant weight on this observation, given the potential endogeneity of both the interest rate and the exchange rate to other more fundamental factors. In consequence, the economics profession remains as divided as it ever was on the topic of appropriate monetary policy during crises.

In this chapter, we first review the theoretical arguments and empirical evidence in support of the two sides of the controversy in greater detail. While this question has given rise to considerable polemics, there have been fewer objective discussions of the pros and cons of monetary tightening during financial crises.

We explore several new means of identifying the impact of interest rates on the value of floating exchange rates. Of the small body of empirical work that has emerged in the aftermath of the Asian crisis, much is subject to the problem discussed above— the endogeneity of both interest rates and exchange rates to other economic forces. Therefore, statistical analysis attempting to explain movements in the exchange rate using interest rate variables alone may be misleading, since during international financial crises, both the interest rate and the exchange rate are likely to be correlated with third factors not accounted for in the analysis.

Our conjecture is that, in the immediate aftermath of devaluation and financial crisis, one of the most important factors influencing the exchange rate is likely to be concerns about the country's ability to pay existing debt. Moreover, changes in the perceived ability to pay are likely to explain the movement in exchange rates more than concerns about interest rate differentials alone. Put another way, the sharp declines in currency values in the affected Asian economies in 1997 and 1998, and the consequent increases in interest rates, probably were 
motivated more by fears of default on debt than by concerns that domestic interest rates were not high enough to offset future inflation and depreciation. Therefore, if one could hold constant investor appraisals of country creditworthiness, it might then be possible to identify the independent impact of changes in interest rates on the exchange rate.

In this chapter, we explore, among other factors, the use of spreads between the countries' dollar-denominated bond yields and U.S. Treasuries as proxies for perceived credit risk. Between July 1997 and July 1998, these yield spreads were reasonably well correlated (negatively) with changes in currency values, providing some support for the view that collapses in currency value may have been caused —at least in part—by mounting fears of default. Our hope is that by adding credit spreads to equations explaining the movements in exchange rates, it may then be possible to identify the independent impact of interest rates on exchange rates, holding all else constant. In our chapter, we estimate equations of this sort using weekly data from the post-devaluation experiences of the affected Asian economies since mid-1997, as well as, for purposes of comparison, Mexico since 1995.

In addition to credit spreads, we also explore the use of several stock market variablesin particular, measures of aggregate stock and of bank stock returns - to control for investor expectations. Because stock market and bank stock returns are proxies for expectations of future profitability in the economy and in the banking sector, their movements may be as reflective of movements in investor perceptions of country risks as movements in credit spreads. Hence, adding stock market returns to our equations for the exchange rate may further reduce the correlation of domestic interest rates with omitted variables in the error term, and hence further enhance our ability to identify independent impacts of interest rates on exchange rates. 
Additionally, adding stock market prices to our equations allows us to explore a key facet of the revisionist hypothesis that a tightening of monetary policy may depreciate the exchange rate. In that hypothesis, monetary tightening leads to this perverse result because it threatens to further weaken the banking system, either indirectly by weakening the overall economy or directly by raising debt-service costs for bank loan recipients. If this hypothesis is correct, then adding measures of the stock market and of bank stocks as explanatory variables to our exchange-rate equations, and thereby holding constant investor perceptions of future profitability in the economy and in the banking sector, should increase the likelihood that increases in interest rates will be estimated to appreciate the exchange rate.

Finally, in addition to estimating equations for the exchange rate itself, we also estimate a broad array of Granger-causality tests among nearly all of the variables used in our analysis. These tests serve two purposes. First, they constitute yet another means of identifying the impact of monetary policy variables on the exchange rate. Second, they provide evidence on the suitability of other explanatory variables—including credit spreads and stock prices—as autonomous measures of investor risk appraisals.

The plan of the chapter is as follows. Section 11.2 reviews the arguments for both a positive and a negative effect of a tightening of monetary policy on the exchange value of the local currency, and briefly surveys previous empirical work on this subject. Section 11.3 outlines the econometric strategy we have developed to identify the impact of monetary policy on exchange rates, while Section 11.4 describes our estimation results. Section 11.5 concludes. 


\subsection{MONETARY POLICY AND EXCHANGE RATES: ARGUMENTS AND EVIDENCE}

\subsubsection{Arguments}

As the Asian crisis evolved, the official international community, and particularly the IMF, argued strongly that, in the aftermath of the floating of national currencies, currency depreciation should be constrained through a tightening of monetary policy. This recommendation was based on several rationales, some of them rooted in the experiences of financial crises and stabilizations in Latin American countries, others responding more directly to the experiences of the Asian countries themselves.

Monetary tightening was considered important for several reasons in the Latin American financial crises of the 1980s, as well as in Mexico in the mid-1990s. First, and most importantly, it could serve to convince private sector agents that monetary policy was under control, thereby acting to reduce inflationary expectations and prevent a vicious cycle of inflation and exchange rate depreciation. Second, by raising the attractiveness of domestic currency assets and thereby limiting exchange rate depreciation, it could accordingly limit imported inflation and thus again prevent the development of an inflationary spiral. Finally, by reducing the level of aggregate demand, monetary tightening not only could reduce inflation, but also could help to cool down the economy, limit imports, improve the balance of payments, and hence improve investor confidence in the countries' prospects for external viability and debt repayment.

These considerations turned out, in retrospect, to be less relevant to the crisis Asian countries in 1997 and 1998 than they were to Latin America in the 1980s or even to Mexico in 1995. To begin with, while Asian exchange rate depreciations were expected to raise inflation 
rates somewhat, there were relatively few concerns that these depreciations would lead to hyperinflationary spirals of rising wages and falling currencies such as had occurred in Latin America. Asian economies had established reputations for relatively low inflation and prudent monetary policy, and only in Indonesia, where the exchange rate collapsed primarily for political reasons, was hyperinflation considered a genuine possibility. Moreover, only in Thailand was the economy considered by some observers to be overheated prior to the crisis, and even then, declines in output and asset prices were taking place by late 1996. Hence, the case for aggregate demand restraint in Asia was limited even at the outset of the crisis, and became more limited still as it became apparent that the economies of the region were moving into very deep recessions.

Notwithstanding these differences with Latin America, however, arguments still were made for the importance of tightening monetary policy in the Asian context. First, even if there was no need to contract aggregate demand, some contended that tightening monetary policy could play a useful role if it restrained the depreciation of exchange rates - the Asian currencies appeared to have declined by far more than was merited by equilibrium considerations alone, and their collapse had helped to roil financial markets and undermine confidence in the region. ${ }^{1}$ Second, a major factor depressing activity and injuring the banking sector had been the effects of depreciating currencies on the balance-sheets of borrowers in foreign currencies; therefore, supporting currencies was actually a way of helping to support the economy and the banking sector, even if pursued through tighter monetary policies. Finally, advocates of tighter monetary policy argued that raising domestic interest rates would support local currencies not only by making domestic-currency assets more attractive, but also by encouraging agents with external 
liabilities to attempt to reschedule these debts rather than finance repayments through borrowings in domestic credit markets; this would have the effect not only of reducing exchange rate depreciation, but also of strengthening the balance of payments by reducing runoffs of foreign liabilities.

Although these arguments are certainly plausible, the IMF's policy recommendations to the crisis Asian economies came under severe criticism as initial increases in interest rates failed to stabilize currencies, as the flow of domestic credit became sharply curtailed, and as these economies moved into very deep recessions. Critics of tighter monetary policy—as expressed most notably in Furman and Stiglitz (1998) and Radelet and Sachs (1998)—contended, among other things, that in the midst of a financial crisis, tightening monetary policy might fail to support the currency and might even increase downward pressures on it. First, in the context of a run on the currency, the level of domestic interest rates required to compensate investors for extreme depreciation expectations might be so high as to be unsustainable and/or extremely injurious to the economy. ${ }^{2}$ Second, in the context of what has been referred to as an "international bank run", with foreign investors determined to pull out of the region, domestic debtors may not have the option of rolling over their external obligations, even if they desire to. Finally, higher interest rates may increase debt-service burdens for firms, lower loan performance, add to pressures on the banking system, and thereby further raise prospects of financial collapse and external debt default, all of which would have the effect of further undermining investor confidence and thereby having a depressive effect on currency values.

On the face of it, both the proponents and critics of monetary tightening to stabilize the exchange rate make plausible arguments, and it is difficult on strictly a priori or theoretical 
grounds to ascertain which side of the issue carries the greater weight. Hence, this debate is more likely to be decided on the basis of actual experience and empirical evidence, a subject to which we now turn.

\subsubsection{Evidence}

Figure 11.1 presents the recent evolution of short-term nominal interest rates and the real exchange rate against the U.S. dollar for the five Asian crisis economies-Indonesia, Korea, Malaysia, the Philippines, and Thailand-as well for Mexico since the onset of its crisis at the end of 1994. In principle, if increases in domestic interest rates lead to appreciations of the exchange rate, then an inverse relationship should be observed between the interest rate and the exchange rate (portrayed as local currency per dollar) in these panels. In fact, as shown in Figure 11.1, in the neighborhood of a currency crisis, domestic interest rates and the local currency value of the dollar are more likely to be positively correlated than negatively correlated; this relationship is quite apparent for Korea, the Philippines, and Mexico, and also applies to some extent in Indonesia, Malaysia, and Thailand.

While this positive relationship between the domestic interest rate and the exchange rate may be indicative of the perverse effects of monetary policy described by Sachs and Radelet (1998), Furman and Stiglitz (1998), and others, it most likely also reflects the fundamental endogeneity of domestic interest rates. The same factors that may cause a floating exchange rate to depreciate-expectations of future depreciation or default on debt-will also cause market interest rates to rise. Additionally, in cases where the monetary authority targets the short-term interest rate, declines in the value of the exchange rate may themselves prompt officials to raise interest rates. 
This endogeneity of domestic interest rates with respect to depreciation expectations, default expectations, and/or recent movements in the exchange rate may obscure the ceteris paribus impact of interest rates on exchange rates, leading to a positive statistical correlation even if, all else equal, tightening monetary policy really does provide support to the local currency in the midst of the crisis. Recent efforts to statistically gauge the impact of domestic interest rates on exchange rates have not managed to fully address this endogeneity problem, and this could explain their relatively limited success in identifying a stable, statistically significant negative impact of domestic interest rates on the local currency value of the dollar.

Research on the effects of monetary policy on exchange rates in emerging market countries has generally taken two approaches. The first of these examines the time-series relationship between exchange rates and interest rates in one or more countries. Results here have been mixed. Goldfajn and Baig (1999) estimate a VAR with first-differenced, daily nominal interest rates and exchange rates in the five Asian crisis economies, and find little impact of interest rates on exchange rates in either direction. Dekle, Hsiao, and Wang (1999) estimate VARs for Korea, Malaysia, and Thailand using weekly differences of nominal exchange rates, prices, and interest rates; they find increases in interest rates generally appreciate the exchange rate, although the significance of this effect varies, depending upon the country and the specification of the equations estimated. Spicer and Goodhart (1999) examine the relationship between daily changes in interest rates, exchange rates and stock prices for Brazil and Korea during their crisis periods. They find little evidence to suggest that increases in interest rates had a significant effect on the exchange rate or the stock market. They argue that this is evidence against the theory that monetary tightness during crises worsens the economic situation. 
An alternative approach toward evaluating the impact of interest rates on exchange rates relies on looking at a large number of devaluation episodes and determining whether, in episodes where monetary policy was tightened, exchange rates were more likely to appreciate than in cases where monetary policy remained loose. Here, also, results have been mixed. Furman and Stiglitz (1998) look at cases where short-term nominal interest rates have been substantially elevated for short periods of time, and find that generally, these episodes are associated with exchange rate depreciation, not appreciation. Conversely, Goldfajn and Gupta (1998) studied a large number of episodes where real exchange rates had become highly depreciated relative to their long-term averages, and assessed whether or not tighter monetary policy made it more likely that subsequent real appreciation would take place through nominal exchange rate appreciation rather than through higher inflation; they found that except in circumstances where financial sectors were under stress, tighter monetary policy—measured as concerted increases in real interest rates-did indeed lead to more nominal exchange rate appreciation. ${ }^{3}$

In sum, evidence on the impact of interest rates on exchange rates during financial crises has been decidedly non-robust. This could reflect the fact that this impact varies considerably from situation to situation, depending upon any number of factors, so that identifying a robust relationship is very difficult. However, it may also be that the prior research has not succeeded in holding constant the factors affecting both interest rates and exchange rates, leading to omitted variable biases that in turn lead econometric results to be extremely unstable.

\subsubsection{A digression on nominal and real interest rates}

An important issue in analyzing the impact of monetary policy on the exchange rate is how to gauge the stance of monetary policy. In principle, the ex ante real interest rate is the most 
appropriate measure of the tightness or looseness of monetary policy, but as inflation expectations generally are not observed directly, frequently the ex post real interest rate must be used instead. Unfortunately, while actual inflation may be a decent proxy for inflation expectations during normal periods, actual inflation may diverge considerably from inflation expectations during financial crises involving sharp depreciations of the exchange rate. Such depreciations may cause short bursts of inflation that cause real ex post interest rates to fall or even become negative temporarily, even though nominal interest rates may have been raised substantially.

This problem may be seen quite readily in Figure 11.2, which compares short-term nominal interest rates with two measures of the ex post real interest rate, one deflated by inflation in the current month, and one deflated over a centered 13-week period. Particularly in the case of Korea and Mexico, even as nominal interest rates were hiked to very high levels, real interest rates fell below zero. Given the impact that high nominal interest rates have on the cash-flow position of corporate and household borrowers, it would seem unreasonable to describe the stance of monetary policy in these episodes as "stimulative". ${ }^{4}$ Therefore, the results of studies that rely on the real interest rate as a measure of monetary stance may be misleading. In the work described below, we analyze separately the impacts of nominal interest rates and inflation on the exchange rate.

\subsection{ECONOMETRIC IDENTIFICATION STRATEGY}

In this section, we discuss our strategy for addressing the endogeneity problem in domestic interest rates and thereby identifying the underlying relationship between exchange rates and interest rates during financial crises. We begin by presenting a simple theoretical 
framework, similar to that outlined in several previous papers on this topic, in order to clarify the discussion. We then outline our own econometric strategy.

\subsubsection{Benchmark theoretical framework}

The standard theory of uncovered interest rate arbitrage suggests that the real interest rate differential between two nations will be a function of the expected real depreciation of the exchange rate and any country risk premium associated with holding foreign currency denominated assets:

$i_{t}-i_{t}^{*}=\left(E_{t+1}^{e}-E_{t}\right)+R P_{t}$

where $i_{t}$ is the domestic real interest rate at time $t, i_{t}^{*}$ is the foreign real interest rate at time $t$, $E_{t+1}^{e}$ is the expected real exchange rate (local currency per dollar) at time $t+1, E_{t}$ is the real exchange rate at time $t$, and $R P_{t}$ is the country risk premium at time $t$. This risk premium incorporates both compensation for exchange rate volatility and, perhaps more important, compensation for the risk of future default on domestic-currency liabilities.

Rearranging equation (1) and solving for $E_{t}$, we get:

$$
E_{t}=-\left(i_{t}-i_{t}^{*}\right)+E_{t+1}^{e}+R P_{t}
$$

Consequently, the standard uncovered interest rate arbitrage condition suggests that increases in real domestic rates relative to foreign rates will appreciate the current real exchange rate (lower $E_{t}$ ), while expected future depreciation and increases in the country risk premium will depreciate the current real exchange rate (raise $E_{t}$ ). Equation (2) forms the basis for most of the empirical analysis that has been conducted on this topic.

Recent arguments against the standard model suggest that raising domestic interest rates 
during a financial crisis can depreciate the exchange rate by increasing the probability of default of domestic borrowers and weakening the asset quality of domestic banks. Another way of describing this phenomenon is that the country risk premium, $R P_{t}$, and the expected future exchange rate, $E_{t+1}^{e}$ are endogenous and are adversely effected by increases in domestic interest rates. $^{5}$ In terms of our theoretical framework, this suggests that, $E_{t+1}^{e}=f\left(i_{t}-i_{t}^{*}\right), \partial E_{t+1}^{e} / \partial i_{t}>0$, and $R P_{t}=g\left(i_{t}-i_{t}^{*}\right), \partial R P_{t} / \partial i_{t}>0$.

Most empirical work on this topic has, in a very broad sense, focused on estimating a variant of equation (2) - but without incorporating a measure of the risk premium or the expected future exchange rate, which are incorporated into the error term-and ascertaining whether the coefficient on the interest rate differential is positive or negative. However, as discussed above, the domestic interest rate $i_{t}$ is likely to be endogenous with respect to both the risk premium $R P$ and the expected future exchange rate $E_{t+l}^{e}$. Therefore, adverse events that raise the risk premium and expected future depreciation are likely to both boost interest rates and depreciate the exchange rate, obscuring any supportive impact that a genuinely autonomous increase in interest rates_-ie, a monetary policy shock—might have on the value of the local currency.

To a certain extent, time series analyses that focus on the effect of lagged interest rates on contemporaneous exchange rates may reduce the severity of the endogeneity problem, but they do not dispel it entirely. First, insofar as movements in the risk premium and the expected future exchange rate may be serially correlated, even the lagged interest rate may be correlated with the error term (which contains the risk premium and expected future exchange rate). Second, to the extent that much of the impact of the interest rate on the exchange rate may take place 
contemporaneously, relying upon lags of the interest rate as the measure of monetary policy may lead to a failure to measure the full impact of monetary policy moves on the exchange rate.

\subsubsection{Empirical strategy}

In order to turn the benchmark model of exchange rate behavior into a testable model, our goal is to develop proxies for the expected future real exchange rate and the country risk premium, thereby taking them out of the error term in an estimated version of equation (2) and accordingly reducing or eliminating the extent of potential omitted variable bias. ${ }^{6}$ The country risk premium is proxied by credit spreads of dollar-denominated government bonds over similar maturity U.S. treasuries. ${ }^{7}$ These spreads are based on market assessments of the probability that governments will default on their external debt, and therefore are likely to move closely with expectations that private institutions will default on their local-currency denominated liabilities.

Expected future real exchange rates are assumed to depend on the expectations of those factors that influence current real exchange rates (i.e., interest rate differentials and country risk premia). Optimally, weekly survey data of market expectations of future exchange rates would be the best proxy for expected real exchange rates. However, because these data are not readily available for the countries in our sample, we assume that expectations of future real exchange rates depend on an adaptive expectations process of past values of interest rate differentials and country risk premia. Consequently, our empirical model includes lagged values of the dependent and independent variables.

The equations estimated take the form of an unrestricted error-correction models for deviations of the real exchange rate from its cointegrating vector, shown in equation (2). The estimating equation is: 


$$
\begin{aligned}
& \Delta E_{t}=\alpha_{0}+\alpha_{1} \sum_{j=1}^{2} \Delta E_{t-j}+\alpha_{2} \sum_{j=0}^{2} \Delta \text { INTDIFF }_{t-j}+\alpha_{3} \sum_{j=0}^{2} \Delta \text { INFDIFF }_{t-j} \\
& +\alpha_{4} \sum_{j=0}^{2} \Delta \text { SPREAD } D_{t-j}+\alpha_{5} E_{t-1}+\alpha_{6} \text { INTDIFF }_{t-1}+\alpha_{7} \text { INFDIFF }_{t-1}+\alpha_{8} \text { SPREAD }_{t-1}+\varepsilon
\end{aligned}
$$

where: $E_{t}$ is the log of the real bilateral exchange rate against the U.S. dollar, INTDIFF $F_{t}$ is the domestic nominal interest rate differential against similar U.S. rates, INFDIFF $F_{t}$ is the domestic inflation against U.S. inflation rates differential (based on a 13-week centered moving average of inflation rates), ${ }^{8}$ and $S P R E A D_{t}$ is the dollar-denominated credit spread for government-issued bonds against similar-maturity U.S. treasuries. The coefficients on the variables expressed in changes may be interpreted as representing the impact effect on the real exchange rate. The coefficients on the lagged levels of the explanatory variables in principle comprise the parameters in a cointegrating vector and hence represent longer-term effects; however, since these equations are estimated over only a year's worth of data, as discussed below, the permanence of these effects should not be over-emphasized.

Finally, we explored using several versions of real stock returns-the log-change in the CPI-deflated index of stock prices—as additional proxies for investor perceptions of depreciation and default risk. In principle, measures of aggregate stock market performance and bank stock performance should represent good proxies for expectations of future economic activity and banking sector health, respectively. Expectations of future economic and banking sector viability, in turn, are likely to be well correlated with investor appraisals of the risk premium and the future expected exchange rate. Therefore, adding stock market variables to equation (3) 
above should help to better control for omitted variables and hence should enhance our ability to identify the impact of monetary policy shocks on the exchange rate.

Additionally, adding stock market variables to the analysis may help to test for the existence of a key channel in the linkage between interest rates and the exchange rate. The revisionist view that tighter monetary policy may actually depreciate the exchange rate depends upon the injurious effect of higher interest rates on economic activity, on corporate loan performance, and on the health of the banking sector. Therefore, if the revisionist view is correct, than when stock market proxies for expected economic and banking sector health are added as explanatory variables to equation (3) above, thereby holding constant the adverse expectational effects of a monetary tightening, it should be more likely that the coefficient on the nominal interest rate differential would adopt its conventionally expected negative sign.

\subsection{ESTIMATION RESULTS}

\subsubsection{Data sample}

Analysis was performed on weekly data for the five countries most heavily affected by the Asian financial crisis: Indonesia, Korea, Malaysia, the Philippines, and Thailand. In addition, in order to get a sense of the generality of these results, we analyzed data for Mexico subsequent to its devaluation. More detailed descriptions of the data and their sources are provided in Appendix A.

The focus of analysis is on the behavior of exchange rates after they have floated and during a period of financial crisis. Therefore, the estimation samples begin at different points in time, depending upon when a country's currency was delinked from the dollar. For the Asian countries, the start of the sample period ranges from the week of July 4, 1997 in the case of 
Thailand to the week of August 15, 1997 in the case of Indonesia. Because Korea's exchange rate was never linked as tightly to the dollar as that of the other Asian countries, the point at which it started floating in earnest is less obviously delineated; accordingly, we have chosen the week of July 4, when the Thai baht was floated, as the starting date for the Korea regressions as well. The sample period for the Mexico regression starts in the week of December 23, 1994, shortly after the peso was floated on December 21.

All of the estimation samples extend through the week of July 31, 1998. This end date was chose for two reasons. First, the focus of this analysis is the behavior of floating exchange rates during financial crises; by the end of July 1998, financial conditions had stabilized to a substantial degree in most of the crisis Asian economies. Second, following the Russian devaluation and default in August 1998, credit spreads on emerging market bonds rose sharply throughout the world. Increases in spreads were not wholly indiscriminate; in Latin America, for example, they backed up most in Brazil and Venezuela, which were indeed regarded as particularly vulnerable. However, the universal nature of the rise, and the lack of precipitating events in many of the countries experiencing the rise, suggest that after July 1998 spreads may have been influenced more by generalized trends in investor liquidity and risk aversion than by country-specific risk factors per se.

In principle, it would be useful to compare the behavior of floating exchange rates during a financial crisis with their behavior during a non-crisis period. Unfortunately, the periods preceding the beginning of our estimation sample cannot be used for this purpose, since during these periods the nominal exchange rate was being pegged (or at least very tightly managed). Moreover, as noted above, much of the post-July 1998 period is contaminated by the after-effects 
of the Russia crisis, when movements in credit spreads appear to have owed more to global factors than to changes in country-specific risks. In the future, however, as more non-crisis observations for Asian financial markets become available, a comparison of crisis and non-crisis exchange rate behavior should be possible.

\subsubsection{Graphical analysis}

In order for credit spreads and stock prices to be useful instruments for identifying monetary policy shocks, these variables must be reasonably well correlated with the exchange rates in the countries under examination. Figure 11.3 presents data on the real exchange rate and credit spreads for the countries in our sample; the vertical line indicates the end of the sample period in July 1998. Up until that date, exchange rates and credit spreads were indeed reasonably well correlated among most of the Asian crisis countries; after that date, spreads moved up far more sharply than the exchange value of the dollar, probably reflecting the global factors discussed above. Interestingly, in Mexico, spreads and exchange rates are highly correlated both before and after the Russian devaluation.

Figures 11.4 and 11.5 present analogous data on exchange rates and centered 5-week moving averages of real stock returns for the entire economy and the banking sector, respectively. (Bank stock returns were not available for the Philippines.) They indicate that, like credit spreads, stock returns are to some extent correlated with real exchange rates, particularly during the period when the crisis was at its most severe.

\subsubsection{Stationarity and cointegration}

Before describing the results of our error-correction regressions, we briefly summarize several of the statistical properties of our data. Table 11.1 presents the results of Dickey-Fuller 
tests applied to the levels and first-differences of the variables used in our analysis. STKRET refers to real aggregate stock returns, and BSTKRET refers to real bank stock returns; because the difference between bank stock returns and aggregate stock returns is used as an explanatory variable in the error-correction regressions, it is this variable that we analyze in the Dickey-Fuller tests.

The results are broadly in line with our expectations. With the exception of the stock returns, the levels of the variables in our analysis generally do not appear to be stationary, while the first-differences of these variables generally do appear to be stationary. The stock return variables clearly are stationary in all instances.

Table 11.2 presents the results of Johansen cointegration tests applied to three different sets of variables: (1) the benchmark model, which does not include stock returns; (2) the benchmark model plus aggregate stock returns; and (3) the benchmark model plus aggregate stock returns and the difference between aggregate and bank stock returns. ${ }^{9}$ For the set of variables in the benchmark model, the tests—based on a comparison of the likelihood ratio with its 95 percent critical value-indicate the presence of at least one cointegrating vector for every country except Korea. For the expanded sets of variables, the tests indicate the presence of at least one cointegrating vector in every country, although this in part reflects the fact that the stock return variables themselves are stationary.

The Johansen tests provide strong prima facie evidence of significant linkages between real exchange rates, interest rates, credit spreads, inflation, and stock returns. The findings of cointegration also strongly support the error-correction specification for our estimated equations. On the other hand, they do not provide much sense of the direction of causality among the 
variables we are analyzing. Therefore, we turn now to a brief description of Granger-causality tests among the variables in the model.

\subsubsection{Granger-causality tests}

In addition to being well-correlated with real exchange rates, a second condition for credit spreads and stock prices to be a good proxy for autonomous movements in investor risk assessments is that they not be themselves influenced, at least contemporaneously, by feedbacks from exchange rates. To address this and a host of other issues involving inter-relationships among the different factors, Table 11.3 presents results of Granger-causality tests among all of the variables in the analysis. In these tests, differences in the "caused" variable were regressed on two lags of itself and of differences in the "causing" variable. Finding Granger causality consisted of using an F-test to reject the hypothesis that the coefficients on the "causing" variable were jointly equal to zero. A number of results stand out.

First, interest rates are found to significantly affect exchange rates in none of the six countries surveyed. This result does not rule out contemporaneous (i.e., within the same week) causality from interest rates to exchange rates, of course. This finding also is subject to some of the same endogeneity problems discussed above, although the use of lagged rather than contemporaneous interest rates to explain the exchange rate may ameliorate this problem to some degree. Nevertheless, this prima facie evidence seems to argue against the view that interest rates have any impact on exchange rates, in either direction.

Second, interest rates were found, with few exceptions, to not significantly Granger-cause credit spreads, aggregate stock prices, or bank stock prices. Hence, the revisionist view that a tightening of monetary policy leads to heightened concerns of future banking sector failures and 
defaults are not supported by these tests, although the same caveats as those mentioned in the previous paragraph still apply.

Third, exchange rates significantly Granger-cause credit spreads, aggregate stock prices, and bank stock prices in only a few instances. This suggests that these measures probably would not be themselves subject to endogeneity problems if used as explanatory variables in exchange rate equations, and hence, to the extent that they capture movements in the risk premium and expected future exchange rate, would serve to minimize endogeneity problems for the interest rate variable.

Fourth, credit spreads do not appear to be particularly influential, at least as measured by the Granger-causality tests. On the other hand, aggregate stock prices and bank stock prices appear to be relatively influential, significantly affecting interest rates, spreads, and exchange rates in numerous instances.

Finally, as a check on the reliability of the results, it should be noted that in most instances where Granger-causality was identified, the sign of the impact was in line with expectations. Hence, increases in credit spreads lead to higher interest rates, more depreciated exchange rates, and lower stock prices. Increases in stock prices (both aggregate and bank stocks) lead to lower interest rates, more appreciated exchange rates, and lower spreads.

\subsubsection{Error-correction estimation results}

11.4.5.1 Benchmark model. Table 11.4a presents the results of unrestricted OLS estimation of equation (3) for the six countries in out sample. For the lagged levels of the explanatory variables, their coefficients and (in parentheses) significance levels are presented; ${ }^{10}$ for the explanatory variables that enter in difference-form, the sums of the coefficients on the different 
lags of each variable are presented, along with their significance. ${ }^{11}$ The following observations can be made about these results.

First, the coefficient on the lagged level of the real exchange rate, $\alpha_{5}$, is appropriately negative and significantly different from zero for every country except Malaysia, suggesting that the error-correction specification used here is appropriate. ${ }^{12}$ Put another way, econometric specifications based on first-differences of the variables alone probably throw away useful information about the mean-reverting properties of the real exchange rate.

Second, the coefficients on the SPREAD term, both its lagged level and its firstdifferences, are highly significant for every country except Malaysia. This is suggestive of a cointegrating relationship containing at least the real exchange rate and the spread, although with only a year's worth of data, one would not want to push that hypothesis too far. In any event, the results confirm the importance of the spread as a near-term determinant of exchange rate movements, consistent with both our hypothesis and with the visual evidence presented in Figure 11.3.

Third, inflation differentials fail to play much of a role in the determination of exchange rate movements among the countries in the sample; in no cases are the coefficients on either the level of this variable or its differences significant at the 5 percent level. In principle, increases in domestic inflation should lead to depreciation of the exchange rate, both because, for a given nominal interest rate, this lowers the real interest rate, and because higher inflation may represent a signal that monetary policy is failing to stabilize the economy. In practice, inflation expectations are hard to measure and may be only loosely related to actual inflation outcomes over short periods of time, particularly since actual outcomes are observed only with a lag. 
Inflation among the Asian economies in the sample generally turned out to be lower than expected, with the possible exception of Indonesia. Even in Mexico, where inflationary impulses were much more apparent, the peak of the financial crisis was reached in March 1995, before inflationary pass-through from the fall of the peso had a chance to fully manifest itself.

Finally, and most importantly, domestic interest rates do not appear to affect the exchange rate in a consistent manner. The coefficients on the lagged levels of the interest rate differential are negative in three countries—which would be consistent with conventional theory—and positive in three countries; the sum of the coefficients on the first-differences are negative in two cases and positive in four. In only two cases where results are significantly different from zerothe coefficient on the lagged level of the interest rate differential for Indonesia, and the coefficients on the first-differences of the interest rate differential for Mexico- - the sign of the effect is negative, consistent with the conventional view that raising domestic interest rates should appreciate the real exchange rate. Interestingly, Indonesia and Mexico also represent the cases where exchange rate depreciation led to significantly higher inflation, and one might expect that in those circumstances, raising interest rates might be more favorably regarded by the market than in cases where inflation and the credibility of monetary policy were not at issue. However, given the paucity of significant coefficients in our estimation results, it is not clear how much weight, if any, should be placed on these findings.

One reason for our failure to identify a more clear-cut impact of the interest rate differential on the exchange rate may be that there are too many parameters-many of them not statistically significant—being estimated in our equations; this is particularly a concern with the first-differenced variables, since there generally are three lags (including the contemporaneous) 
of each of them. To address this potential problem, we progressively reduced the number of parameters in the equations by deleting the least significant of the first-differenced explanatory variables from the models, re-estimating them, and proceeding in this fashion until only relatively significant parameters-usually in the neighborhood of the 5 percent level of significance-remained for the first-differenced variables in the equations; all of the lagged levels of the explanatory variables were retained.

The estimation results for these more parsimonious models are presented in Table 11.4b, which displays coefficient values and levels of significance for each of the coefficients in the equations. While some coefficients are now significant that were not in the unrestricted models, the basic findings are not much changed. With the exception of Malaysia, the coefficients on the lagged levels of the exchange rate and the spread remain highly significant and with the expected sign. Some coefficients on the inflation variables-both in levels and first-differences-are now significant, but there is no consistency as to their sign. Finally, the findings for the interest differential remain essentially unchanged; while a negative and significant coefficient on the second lag of the first-differenced interest rate differential is now indicated for Korea, there also is now a positive and significant contemporaneous value of the first-differenced interest rate differential for the Philippines.

11.4.5.2 Model with aggregate stock returns. Table 11.5a presents the estimation results for the unrestricted model when the lagged level of stock returns - defined as the log-change in a broad, price-deflated stock price index — and several lags of the first-difference of stock returns are added to the model presented in Table 11.4a. As noted above, if higher interest rates lead to a depreciation of the exchange rate by raising concerns about future economic performance and 
debt repayment, as contended by some observers, than adding stock returns to the equations presented in Tables 11.4a and 11.4b, by holding these concerns constant, should lead to stronger estimates of a negative effect of interest rates on the local currency value of the dollar.

As indicated in Table 11.5a, the lagged level of stock returns is negative in five of the six cases, consistent with our expectations that improved expectations of economic performance lead to a stronger exchange rate, and is approximately significant in three of those cases. The sum of the lags on the first-difference of stock returns also is significant in a number of cases, albeit with the wrong sign.

However, the addition of the stock return variables makes no appreciable difference to the estimated effect of the interest rate differential, either in levels or in first-differences, on the real exchange rate. The same holds for the estimated effect of the interest rate differential in the parsimonious regression results presented in Table 11.5b.

11.4.5.3 Model with both aggregate and bank stock returns. The story that tightening monetary policy leads to a depreciation of the exchange rate focuses most closely on the impact of higher interest rates on the health of the banking system. Therefore, in Table 11.6a, we add to the model presented in Table 11.5a measures of the difference between aggregate stock returns and bank stock returns; this specification was chosen so as to include both aggregate and bank returns in the same model, while minimizing the extent of multicollinearity between them. Table 11.6b presents results for the parimonious version of the model represented in Table 11.6a.

As a quick perusal of the tables will indicate, the addition of bank stock return variables makes little difference to the results, either relative to those shown in Tables $11.4 \mathrm{a}$ and $11.4 \mathrm{~b}$ or those shown in Tables 11.5a and 11.5b. 


\subsection{Conclusion}

In this chapter, we attempt to make a contribution to an important policy debate that has arisen in the aftermath of the Asian financial crisis: to what extent can a tightening of monetary policy prevent a depreciation of a floating exchange rate in the midst of a financial and balanceof-payment crisis? This debate is sufficiently balanced in theoretical terms that it likely will only be settled on empirical grounds. However, a crucial obstacle to the empirical resolution of this issue is that while domestic interest rates may exert certain impacts on the exchange rate, these interest rates also are highly sensitive to the same factors than influence the exchange rate, especially investor perceptions of country risk. Therefore, prior attempts to assess the impact of interest rates on the exchange rate may have been adversely affected by endogeneity and omitted variable problems.

In our chapter, we attempt to address these endogeneity problems by including dollardenominated sovereign credit spreads - a measure of investor perceptions of country risk-in regression equations for the exchange rates of the crisis Asian economies. In principle, if increases in domestic interest rates really help support the exchange rate, this effect should have become apparent once this measure of investor perceptions was held constant in the equations. In fact, we find that credit spreads exerted a consistent and strongly significant impact on exchange rates for nearly all of the countries in our sample, consistent with our hypothesis that during financial crises, perceptions of country and credit risk become a major determinant of currency values. Nevertheless, even with credit spreads included as explanatory variables, we find little consistent evidence of an effect of interest rates on the exchange rate-either positive or negative-in our estimation results. 
These findings are consistent with one of three different possibilities. First, it may be that there is no systematic effect of monetary policy on exchange rates, at least over the relatively limited time horizon—about a year's worth of weekly data-examined in our study. Second, it is possible that the inclusion of credit spreads, statistically significant as they are, nevertheless fails to correct the endogeneity of the domestic interest rate with respect to omitted variables. Finally, it may be the case that when monetary policy is tightened, the forces appreciating the exchange rate and depreciating the exchange rate are sufficiently well balanced that, on net, little systematic and identifiable change to the exchange rate actually occurs.

In order to assess these last two possibilities, we added to our benchmark regression model several measures of aggregate and banking-sector stock returns. These returns should reflect investor expectations of future prospects for the economy and the banking sector, and hence represent additional measures of investor assessments of country risk. Therefore, it is possible that the addition of stock returns could help to better identify the independent impact of monetary policy shocks on the exchange rate. Moreover, if a tightening of monetary policy tends to depress investor expectations and therefore depress the value of the local currency, holding stock returns constant should remove this effect from the estimated impact of interest rates on exchange rates. In consequence, compared with equations that do not include these stock returns, equations that include these returns as explanatory variables should be more likely to show a supportive effect of a monetary tightening on the exchange value of the local currency.

In fact, inclusion of stock market variables does little to change the minimal effect of interest rates on exchange rates estimated in our benchmark model. This finding would tend to diminish support for the view that, all else equal, monetary tightening undercuts the value of the 
exchange rate by depressing the economy or threatening the health of the banking sector. It also makes it less likely that the failure to identify consistent significant impacts of domestic interest rates on exchange rates reflects endogeneity problems, insofar as the combination of credit spreads and stock returns should in principle be adequate to control for movements in investor concerns about country risk and future depreciation. Hence, it diminishes support for the view that monetary tightening appreciates the exchange rate as well.

We are therefore left with two possibilities. One is that monetary policy simply has no effect on the exchange rate. While one would not want to dismiss this possibility out of hand, it contradicts so much of the theory of international finance that to accept it would require rejecting nearly everything else we believe about the international financial system. Such a conclusion also fails to present any guidance for the conduct of monetary policy.

An alternative, and perhaps more likely, possibility is that monetary policy may indeed impact exchange rates in a systematic way, but only slowly and over relatively long time horizons, so that this impact would not be identified using weekly data over a relatively short one-year sample. In principle, of course, changes in monetary policy should have immediate effects on exchange rates and other asset prices in a free market with forward-looking investors. In practice, however, investors may have concerns that monetary policy actions might subsequently be reversed. It may take a sustained period of monetary tightness, for example, to establish the credibility of the central bank, convince market participants that the time is right to invest, and thereby strengthen the domestic currency. If this is the case, studies encompassing many financial crisis episodes, such as Furman and Stiglitz (1998) and Goldfajn and Gupta 
(1998), would be more likely to identify significant impacts of interest rates on exchange rates during financial crises.

Unfortunately, as noted earlier in this chapter, such studies have not, to date, provided any clear and consistent answers to the question of what impact monetary policy may have on the exchange rate. In the absence of such answers, what guidance is available to policymakers? The conclusion we draw, both from the theoretical arguments and the empirical results (or lack thereof), is that during financial crises, monetary policy should strive to be prudent, to establish credibility, and to avoid extremes of tightness or looseness. Such an approach would dictate maintaining positive real ex post interest rates, for example, but not necessarily over very short intervals, if temporary bursts of inflation would require unsustainably high nominal interest rates as a result. Such an approach would in general dictate discernable increases in nominal interest rates during financial crisis, if only to signal to the market that containing an inflation/depreciation spiral is a high priority of the monetary authority. At the same time, however, such an approach would argue against raising interest rates "through the roof" during a financial crisis, as that might well trigger concerns about the future viability of the banking system and the country's creditworthiness.

The definition of what constitutes an excessive increase in interest rates, of course, will vary from country to country. In post-devaluation Mexico (1995) and Brazil (1999), strong inflation expectations and the low credibility of monetary policy dictated extremely high interest rates. Conversely, in the crisis Asian countries, where inflation expectations were lower and the credibility of monetary policy higher, smaller increases in interest rates may have been required to support the stability of financial markets. 
In conclusion, the impact of monetary policy on exchange rates during financial crises remains a very controversial and very important issue. Much more empirical work will be required if this issue is to be resolved. 


\section{REFERENCES}

Dekle, Robert, Cheng Hsiao, and Siy`an Wang (1999), “Interest Rate Stabilization of Exchange Rates and Contagion in the Asian Crisis Countries", working paper, University of Southern California.

Goldfajn, Ilan and Poonam Gupta (1998), “Does Monetary Policy Stabilize the Exchange Rate?” working paper, International Monetary Fund.

Goldfajn, Ilan and Tamur Baig (1999), "Monetary Policy in the Aftermath of Currency Crises: The Case of Asia", working paper, PUC/Rio.

International Monetary Fund (1998), “Box 2.3 The Role of Monetary Policy in Responding to Currency Crises", in World Economic Outlook, Washington, D.C., August.

Kraay, Art (1998), "Do High Interest Rates Defend Currencies During Speculative Attacks?" working paper, World Bank.

Furman, Jason and Joseph E. Stiglitz (1998), "Economic Crises: Evidence and Insights from East Asia”, Brookings Papers on Economic Activity, 2.

Radelet, Steven and Jeffrey D. Sachs (1998), “The East Asian Financial Crisis: Diagnosis, Remedies, Prospects," Brookings Papers on Economic Activity, 1.

Spicer, John and Charles Goodhart (1999) “Monetary Policy’s Effects During the Recent Financial Crises in Brazil and Korea," working paper, Bank of England. 


\section{ENDNOTES}

\footnotetext{
${ }^{1}$ See IMF (1998) for a useful discussion of the pros and cons of tightening monetary policy during financial crises, including the Asian crisis. The article also articulates the IMF case for a tightening of monetary policy in these circumstances.
}

${ }^{2}$ This point is underscored in Furman and Stiglitz (1998). For example, consider a situation in which the exchange rate is expected to depreciate by 10 percent against the dollar in the coming month. In order to induce an investor to hold an domestic-currency asset (with no default risk), the domestic interest rate would have to be roughly 10 percentage points higher than U.S. interest rates on a monthly basis, but over 200 percentage points higher on an annual basis!

${ }^{3}$ Kraay (1998) looks at factors determining whether or not defenses of a fixed peg against speculative attack succeed, and concludes that tightening monetary policy does not increase the likelihood of a successful defense. It is not clear, however, whether these results, even if deemed correct for pegged exchange rate regimes, would apply to the impact of interest rates on exchange rates in floating exchange rate regimes.

${ }^{4}$ The case of Mexico in early 1995 is illustrative. Short-term interest rates rose close to 100 percent at certain points, and with much domestic bank debt either at floating rates or very short term, borrowers were hard-pressed to service their debt. The fact that CPI inflation was running even higher provided little short-term cash-flow relief, even if it did contribute to making the bank loans more repayable in the longer run. Moreover, because the inflation spike was concentrated in tradeable goods, many firms may have seen the nominal interest rates on their debt skyrocket even as the nominal value of their assets rose by far less.

${ }^{5}$ While it is obvious why the risk premium should rise in the event of greater stress on the domestic financial sector—-this raises the probability that banks and other borrowers will default on their liabilities—it is less obvious why the expected future exchange rate should depreciate under those conditions. In the very long term, the expected future exchange rate should be determined by the economy's equilibrium exchange rate, which in turn depends on trends in productivity and preferences. In the shorter term, however, the expected future exchange rate is likely to 
depend upon the economy's prospective balance-of-payments position. A bankrupt and defaulting financial sector will likely be associated with a cessation of net capital inflows, requiring a more depreciated real exchange rate as a result.

${ }^{6}$ A more common approach to endogeneity problems is to use IV estimation to instrument for the endogenous explanatory variable. However, this would require finding instruments that are correlated with the interest rate and yet uncorrelated with the error term, that is, the risk premium and expected future exchange rate. Given that we can identify no such instrument, we have instead opted for the approach of controlling for as much of the risk premium and expected future exchange rate as possible, thereby (hopefully) shrinking the variability of the error term sufficiently to minimize endogeneity problems.

${ }^{7}$ See the data appendix for a detailed description of the data and data sources.

${ }^{8}$ In principle, the domestic nominal interest differentials and the inflation differentials could be combined to form a real interest rate differential. However, as discussed in Section II.3 above, it is extremely uncertain what specification of actual inflation rates best captures the inflation expectations that are part of an ex ante real interest rate. Moreover, as will be shown below, the empirical results clearly fail to support a restriction tying the coefficients on the inflation differential to be equal in magnitude and opposite in value to those on the interest rate differential.

${ }^{9}$ This formulation was adopted to reduce the extent of multicollinearity between aggregate and banking sector stock returns.

${ }^{10}$ Specifically, the significance level is the probability that the coefficient might actually be equal to zero, given its estimated value and standard deviation. 
${ }^{11}$ More precisely, for the explanatory variables entering in differences, the significance level is based on an F-test of the null hypothesis that the coefficients jointly are equal to zero.

${ }^{12}$ The phrase "statistically significant" is used in an impressionistic rather than exact sense in this context. Since the levels of the explanatory variables are not necessarily stationary, their standards errors may well be biased, leading to misleading inferences of significance in some cases. 


\begin{tabular}{|c|c|c|}
\hline Variable & Description & Source \\
\hline$E$ & $\begin{array}{l}\text { Weekly log real bilateral } \\
\text { exchange rate relative to the } \\
\text { U.S. dollar. Weekly domestic } \\
\text { and foreign inflation rates are } \\
\text { described below. }\end{array}$ & $\begin{array}{l}\text { Authors' calculations from } \\
\text { Bloomberg exchange rate data and } \\
\text { country government CPI data. }\end{array}$ \\
\hline INTDIFF & $\begin{array}{l}\text { One month domestic interest } \\
\text { rate differential with respect to } \\
\text { the one month U.S. T-bill. }\end{array}$ & $\begin{array}{l}\text { Data derived from: } \\
\text { Indonesia: JIBOR } 1 \text { mo. rate. } \\
\text { Korea: Seoul } 15 \text { day interbank rate. } \\
\text { Malaysia: KLIBOR } 1 \text { mo. rate. } \\
\text { Thailand: BIBOR } 1 \text { mo. rate. } \\
\text { Mexico: } 28 \text { day CETES rate. } \\
\text { Philippines: PHIBOR } 1 \text { mo. rate. }\end{array}$ \\
\hline INFDIFF & $\begin{array}{l}\text { Domestic inflation rate } \\
\text { differential with respect to the } \\
\text { U.S inflation rate. Weekly } \\
\text { inflation rates were derived by } \\
\text { distributing the monthly rate } \\
\text { equally over the number of } \\
\text { weeks in the month and then a } \\
13 \text { week rolling change was } \\
\text { calculated. These data are at } \\
\text { annual rates }\end{array}$ & $\begin{array}{l}\text { Authors' calculations from } \\
\text { government data sources. }\end{array}$ \\
\hline SPREAD & $\begin{array}{l}\text { Government bonds spreads } \\
\text { against similar maturity and } \\
\text { coupon of U.S. government } \\
\text { bond spreads. }\end{array}$ & Derived from Bloomberg data. \\
\hline STKRET & $\begin{array}{l}\text { Weekly total stock market } \\
\text { return calculated as the log } \\
\text { difference in the weekly total } \\
\text { CPI-deflated stock market } \\
\text { index. }\end{array}$ & Derived from Bloomberg data. \\
\hline BSTKRET - STKRET & $\begin{array}{l}\text { Weekly bank stock index } \\
\text { return minus weekly total } \\
\text { stock market return. }\end{array}$ & $\begin{array}{l}\text { Authors' calculations from } \\
\text { Bloomberg stock market data. }\end{array}$ \\
\hline
\end{tabular}


Table 11.1. Unit root tests: augmented Dickey-Fuller test statistics

\begin{tabular}{|c|c|c|c|c|c|c|}
\hline & Indonesia & Korea & Malaysia & Mexico & Philippines & Thailand \\
\hline$\Delta E$ & -3.212 & -3.303 & -4.305 & -7.152 & -3.560 & -4.067 \\
\hline$\triangle I N T D I F F$ & -4.861 & -3.663 & -6.532 & -6.187 & -5.739 & -4.533 \\
\hline$\triangle I N F D I F F$ & -1.637 & -1.242 & -1.266 & -2.162 & -2.095 & -1.489 \\
\hline$\triangle S P R E A D$ & -3.802 & -3.979 & -5.791 & -8.985 & -5.020 & -4.149 \\
\hline$\triangle S T K R E T$ & -6.908 & -7.915 & -8.225 & -13.349 & -7.181 & -7.892 \\
\hline$\triangle(B S T K R E T-S T K R E T)$ & -4.972 & -4.293 & -3.738 & -7.841 & & -4.992 \\
\hline E & -1.664 & -1.408 & -1.094 & -3.065 & -1.839 & -1.993 \\
\hline INTDIFF & -0.953 & -1.645 & -1.692 & -1.972 & -1.976 & -2.768 \\
\hline$I N F D I F F$ & -1.134 & -1.051 & -1.053 & -1.832 & -0.509 & -1.638 \\
\hline SPREAD & -1.277 & -1.721 & 0.295 & -2.187 & -2.021 & -1.835 \\
\hline STKRET & -4.228 & -3.545 & -4.115 & -8.006 & -4.331 & -4.212 \\
\hline BSTKRET - STKRET & -4.971 & -4.293 & -3.738 & -7.841 & & -4.992 \\
\hline 95\% Critical value* & -2.919 & -2.912 & -2.912 & -2.877 & -2.915 & -2.914 \\
\hline Period of observation & $\begin{array}{l}8 / 15 / 97 \\
\text { to } \\
7 / 31 / 98\end{array}$ & $\begin{array}{l}7 / 04 / 97 \\
\text { to } \\
7 / 31 / 98\end{array}$ & $\begin{array}{l}7 / 04 / 97 \\
\text { to } \\
7 / 31 / 98\end{array}$ & $\begin{array}{l}12 / 23 / 94 \\
\text { to } \\
7 / 31 / 98\end{array}$ & $\begin{array}{l}7 / 18 / 97 \\
\text { to } \\
7 / 31 / 98\end{array}$ & $\begin{array}{l}7 / 11 / 97 \\
\text { to } \\
7 / 31 / 98\end{array}$ \\
\hline
\end{tabular}

* MacKinnon critical value for rejection of the hypothesis of a unit root. The augmented Dickey-Fuller tests included two lags and a constant term. 
Table 11.2. Johansen cointegration tests

Benchmark Model: $E=a * I N T D I F F+b * I N F D I F F+c * S P R E A D$

\begin{tabular}{|c|c|c|c|c|c|c|}
\hline & Indonesia & Korea & Malaysia & Mexico & Philippines & Thailand \\
\hline Maximum eigenvalue & 0.4987 & 0.3861 & 0.3873 & 0.1833 & 0.3916 & 0.5458 \\
\hline Likelihood ratio test & 43.76 & 34.94 & 41.56 & 61.96 & 49.45 & 59.71 \\
\hline $95 \%$ Critical value* & 39.89 & 39.89 & 39.89 & 39.89 & 39.89 & 39.89 \\
\hline Period of observation & $\begin{array}{l}8 / 15 / 97 \\
\text { to } \\
7 / 31 / 98\end{array}$ & $\begin{array}{l}7 / 04 / 97 \\
\text { to } \\
7 / 31 / 98\end{array}$ & $\begin{array}{l}7 / 04 / 97 \\
\text { to } \\
7 / 31 / 98\end{array}$ & $\begin{array}{l}12 / 23 / 94 \\
\text { to } \\
7 / 31 / 98\end{array}$ & $\begin{array}{l}7 / 18 / 97 \\
\text { to } \\
7 / 31 / 98\end{array}$ & $\begin{array}{l}7 / 11 / 97 \\
\text { to } \\
7 / 31 / 98\end{array}$ \\
\hline
\end{tabular}

* Null hypothesis is that there are no cointegrating vectors.

Model: $E=a * I N T D I F F+b * I N F D I F F+c * S P R E A D+d * S T K R E T$

\begin{tabular}{lllllll}
\hline \hline & Indonesia & Korea & Malaysia & Mexico & Philippines & Thailand \\
\hline Maximum eigenvalue & 0.6654 & 0.6792 & 0.4817 & 0.4199 & 0.5451 & 0.6991 \\
Likelihood ratio test & 85.56 & 89.90 & 79.94 & 158.88 & 91.01 & 97.64 \\
95\% Critical value* & 59.46 & 59.46 & 59.46 & 59.46 & 59.46 & 59.46 \\
Period of observation & $\begin{array}{l}8 / 15 / 97 \\
\text { to }\end{array}$ & $\begin{array}{l}7 / 04 / 97 \\
\text { to }\end{array}$ & $\begin{array}{l}7 / 04 / 97 \\
\text { to }\end{array}$ & $\begin{array}{l}12 / 23 / 94 \\
\text { to }\end{array}$ & $7 / 18 / 97$ & $\begin{array}{l}7 / 11 / 97 \\
\text { to }\end{array}$ \\
& $7 / 31 / 98$ & $7 / 31 / 98$ & $7 / 31 / 98$ & $7 / 31 / 98$ & $7 / 31 / 98$ & $7 / 31 / 98$ \\
\hline \hline
\end{tabular}

* Null hypothesis is that there are no cointegrating vectors.

Model: $E=a * I N T D I F F+b * I N F D I F F+c * S P R E A D+d * S T K R E T+e *($ BSTKRET-STKRET $)$

\begin{tabular}{lllllll}
\hline \hline & Indonesia & Korea & Malaysia & Mexico & Philippines & Thailand \\
\hline Maximum eigenvalue & 0.8100 & 0.6962 & 0.5951 & 0.4249 & & 0.7208 \\
& 149.79 & 121.23 & 117.45 & 235.43 & & 153.56 \\
Likelihood ratio test & & 82.49 & 82.49 & 82.49 & & 82.49 \\
$95 \%$ Critical value* & 82.49 & & & & & \\
& $8 / 15 / 97$ & $7 / 04 / 97$ & $7 / 04 / 97$ & $12 / 23 / 94$ & $7 / 18 / 97$ & $7 / 11 / 97$ \\
Period of observation & $\begin{array}{l}\text { to } \\
\text { to }\end{array}$ & to & to & to & to \\
& $7 / 31 / 98$ & $7 / 31 / 98$ & $7 / 31 / 98$ & $7 / 31 / 98$ & $7 / 31 / 98$ & $7 / 31 / 98$ \\
\hline \hline
\end{tabular}

* Null hypothesis is that there are no cointegrating vectors. 
Table 11.3. Granger-causality tests

\begin{tabular}{|c|c|c|c|c|c|c|}
\hline & Indonesia & Korea & Malaysia & Mexico & Philippines & Thailand \\
\hline $\mathrm{i} \rightarrow$ spreads & 0 & 0 & 0 & $-* *$ & 0 & 0 \\
\hline $\mathrm{i} \leftarrow$ spreads & 0 & 0 & 0 & $+* * *$ & 0 & 0 \\
\hline $\mathrm{i} \rightarrow$ ex-rate & 0 & 0 & 0 & 0 & 0 & 0 \\
\hline $\mathrm{i} \leftarrow$ ex-rate & 0 & $+* * *$ & 0 & $+* * *$ & 0 & 0 \\
\hline $\mathrm{i} \rightarrow$ stocks & 0 & 0 & 0 & 0 & 0 & 0 \\
\hline $\mathrm{i} \leftarrow$ stocks & 0 & -* & 0 & $-* *$ & 0 & $-* * *$ \\
\hline spread $\rightarrow$ stocks & 0 & 0 & 0 & 0 & -** & 0 \\
\hline spread $\leftarrow$ stocks & 0 & -**** & $-* *$ & $-* * *$ & 0 & $-* * *$ \\
\hline ex-rates $\rightarrow$ spread & 0 & $+* *$ & 0 & 0 & 0 & $+* * *$ \\
\hline ex-rates $\leftarrow$ spread & $+* *$ & 0 & 0 & $+* *$ & 0 & 0 \\
\hline ex-rates $\rightarrow$ stocks & $+* * *$ & 0 & 0 & 0 & 0 & 0 \\
\hline ex-rates $\leftarrow$ stocks & 0 & 0 & $-*$ & $-* *$ & 0 & 0 \\
\hline $\mathrm{i} \rightarrow$ bank stocks & 0 & 0 & 0 & $-*$ & & 0 \\
\hline $\mathrm{i} \leftarrow$ bank stocks & 0 & $-* * *$ & 0 & $-* * *$ & & -** \\
\hline bank stocks $\rightarrow$ spread & 0 & $-* * *$ & 0 & $-* *$ & & $-* * *$ \\
\hline bank stocks $\leftarrow$ spread & 0 & 0 & 0 & 0 & & -* \\
\hline bank stocks $\rightarrow$ ex-rate & 0 & -**** & -** & 0 & & -* \\
\hline bank stocks $\leftarrow$ ex-rate & 0 & 0 & 0 & $-*$ & & 0 \\
\hline bank stocks $\rightarrow$ stocks & 0 & $+* *$ & 0 & -* & & 0 \\
\hline bank stocks $\leftarrow$ stocks & $+^{*}$ & 0 & 0 & $+* *$ & & 0 \\
\hline
\end{tabular}

Note: *Significant at the $10 \%$ Level. **Significant at the 5\% Level. ***Significant at the 1\%level. The regressions take the form: $y_{t}=\alpha_{0}+\alpha_{1} y_{t-1}+\alpha_{2} y_{t-2}+\alpha_{3} x_{t-1}+\alpha_{4} x_{t-2}+\varepsilon$. Significance of the Granger-causality text is determined by an F-test of the null hypothesis that $\alpha_{3}=0$ and $\alpha_{4}=0$. 
Table 11.4a. ECM estimation: benchmark model

Dependent variable: $\Delta E_{t}$

\begin{tabular}{|c|c|c|c|c|c|c|}
\hline & Indonesia & Korea & Malaysia & Mexico & Philippines & Thailand \\
\hline Constant & $\begin{array}{l}1.675 \\
(0.029)\end{array}$ & $\begin{array}{l}2.215 \\
(0.009)\end{array}$ & $\begin{array}{l}0.066 \\
(0.914)\end{array}$ & $\begin{array}{l}0.267 \\
(0.053)\end{array}$ & $\begin{array}{l}0.991 \\
(0.030)\end{array}$ & $\begin{array}{l}1.827 \\
(0.001)\end{array}$ \\
\hline$\sum_{j=1}^{2} \alpha_{1 j} \Delta E_{t-j}$ & $\begin{array}{l}-0.024 \\
(0.225)\end{array}$ & $\begin{array}{l}0.124 \\
(0.485)\end{array}$ & $\begin{array}{l}-0.534 \\
(0.111)\end{array}$ & $\begin{array}{l}-0.005 \\
(0.223)\end{array}$ & $\begin{array}{l}-0.264 \\
(0.344)\end{array}$ & $\begin{array}{l}0.475 \\
(0.053)\end{array}$ \\
\hline$\sum_{j=0}^{2} \alpha_{2 j} \Delta I N T D I F F_{t-j}$ & $\begin{array}{l}0.003 \\
(0.332)\end{array}$ & $\begin{array}{l}-0.002 \\
(0.626)\end{array}$ & $\begin{array}{l}0.010 \\
(0.640)\end{array}$ & $\begin{array}{l}-0.001 \\
(0.005)\end{array}$ & $\begin{array}{l}0.004 \\
(0.289)\end{array}$ & $\begin{array}{l}0.004 \\
(0.493)\end{array}$ \\
\hline$\sum_{j=0}^{2} \alpha_{3 j} \Delta I N F D I F F_{t-j}$ & $\begin{array}{l}-0.007 \\
(0.198)\end{array}$ & $\begin{array}{l}0.002 \\
(0.317)\end{array}$ & $\begin{array}{l}-0.201 \\
(0.656)\end{array}$ & $\begin{array}{l}-0.0005 \\
(0.467)\end{array}$ & $\begin{array}{l}-0.024 \\
(0.601)\end{array}$ & $\begin{array}{l}0.015 \\
(0.134)\end{array}$ \\
\hline$\sum_{j=0}^{2} \alpha_{4 j} \Delta S P R E A D_{t-j}$ & $\begin{array}{l}0.041 \\
(0.000)\end{array}$ & $\begin{array}{l}0.034 \\
(0.004)\end{array}$ & $\begin{array}{l}-0.005 \\
(0.989)\end{array}$ & $\begin{array}{l}0.024 \\
(0.000)\end{array}$ & $\begin{array}{l}0.001 \\
(0.002)\end{array}$ & $\begin{array}{l}-0.029 \\
(0.069)\end{array}$ \\
\hline$\alpha_{5} E_{t-1}$ & $\begin{array}{l}-0.352 \\
(0.035)\end{array}$ & $\begin{array}{l}-0.492 \\
(0.009)\end{array}$ & $\begin{array}{l}-0.0004 \\
(0.996)\end{array}$ & $\begin{array}{l}-0.058 \\
(0.051)\end{array}$ & $\begin{array}{l}-0.227 \\
(0.036)\end{array}$ & $\begin{array}{l}-0.415 \\
(0.001)\end{array}$ \\
\hline$\alpha_{6}{I N T D I F F_{t-1}}$ & $\begin{array}{l}-0.005 \\
(0.015)\end{array}$ & $\begin{array}{l}0.004 \\
(0.316)\end{array}$ & $\begin{array}{l}-0.011 \\
(0.418)\end{array}$ & $\begin{array}{l}-0.0002 \\
(0.958)\end{array}$ & $\begin{array}{l}0.0004 \\
(0.862)\end{array}$ & $\begin{array}{l}0.005 \\
(0.252)\end{array}$ \\
\hline$\alpha_{7}{I N F D I F F_{t-1}}$ & $\begin{array}{l}-0.001 \\
(0.211)\end{array}$ & $\begin{array}{l}0.004 \\
(0.147)\end{array}$ & $\begin{array}{l}-0.002 \\
(0.462)\end{array}$ & $\begin{array}{l}-0.0002 \\
(0.092)\end{array}$ & $\begin{array}{l}-0.0003 \\
(0.940)\end{array}$ & $\begin{array}{l}0.005 \\
(0.057)\end{array}$ \\
\hline$\alpha_{8} S P R E A D_{t-1}$ & $\begin{array}{l}0.096 \\
(0.002)\end{array}$ & $\begin{array}{l}0.045 \\
(0.029)\end{array}$ & $\begin{array}{l}0.004 \\
(0.868)\end{array}$ & $\begin{array}{l}0.003 \\
(0.011)\end{array}$ & $\begin{array}{l}0.031 \\
(0.038)\end{array}$ & $\begin{array}{l}0.043 \\
(0.012)\end{array}$ \\
\hline Period of observation & $\begin{array}{l}8 / 15 / 97 \\
\text { to } \\
7 / 31 / 98\end{array}$ & $\begin{array}{l}7 / 04 / 97 \\
\text { to } \\
7 / 31 / 98\end{array}$ & $\begin{array}{l}7 / 04 / 97 \\
\text { to } \\
7 / 31 / 98\end{array}$ & $\begin{array}{l}12 / 23 / 94 \\
\text { to } \\
7 / 31 / 98\end{array}$ & $\begin{array}{l}7 / 18 / 97 \\
\text { to } \\
7 / 31 / 98\end{array}$ & $\begin{array}{l}7 / 11 / 97 \\
\text { to } \\
7 / 31 / 98\end{array}$ \\
\hline Observations & 51 & 57 & 57 & 176 & 55 & 56 \\
\hline Adjusted $\mathrm{R}^{2}$ & 0.65 & 0.31 & 0.03 & 0.58 & 0.32 & 0.14 \\
\hline Regression std. error & 0.083 & 0.051 & 0.047 & 0.011 & 0.037 & 0.038 \\
\hline $\begin{array}{l}\text { LM (significance } \\
\text { level)* }\end{array}$ & 0.933 & 0.792 & 0.518 & 0.633 & 0.892 & 0.850 \\
\hline
\end{tabular}

Note: Significance levels in parentheses.

* LM test for autocorrelation of errors; null hypothesis is that there is no autocorrelation. 
Table 11.4b. ECM estimation: parsimonious benchmark model

Dependent variable: $\Delta E_{t}$

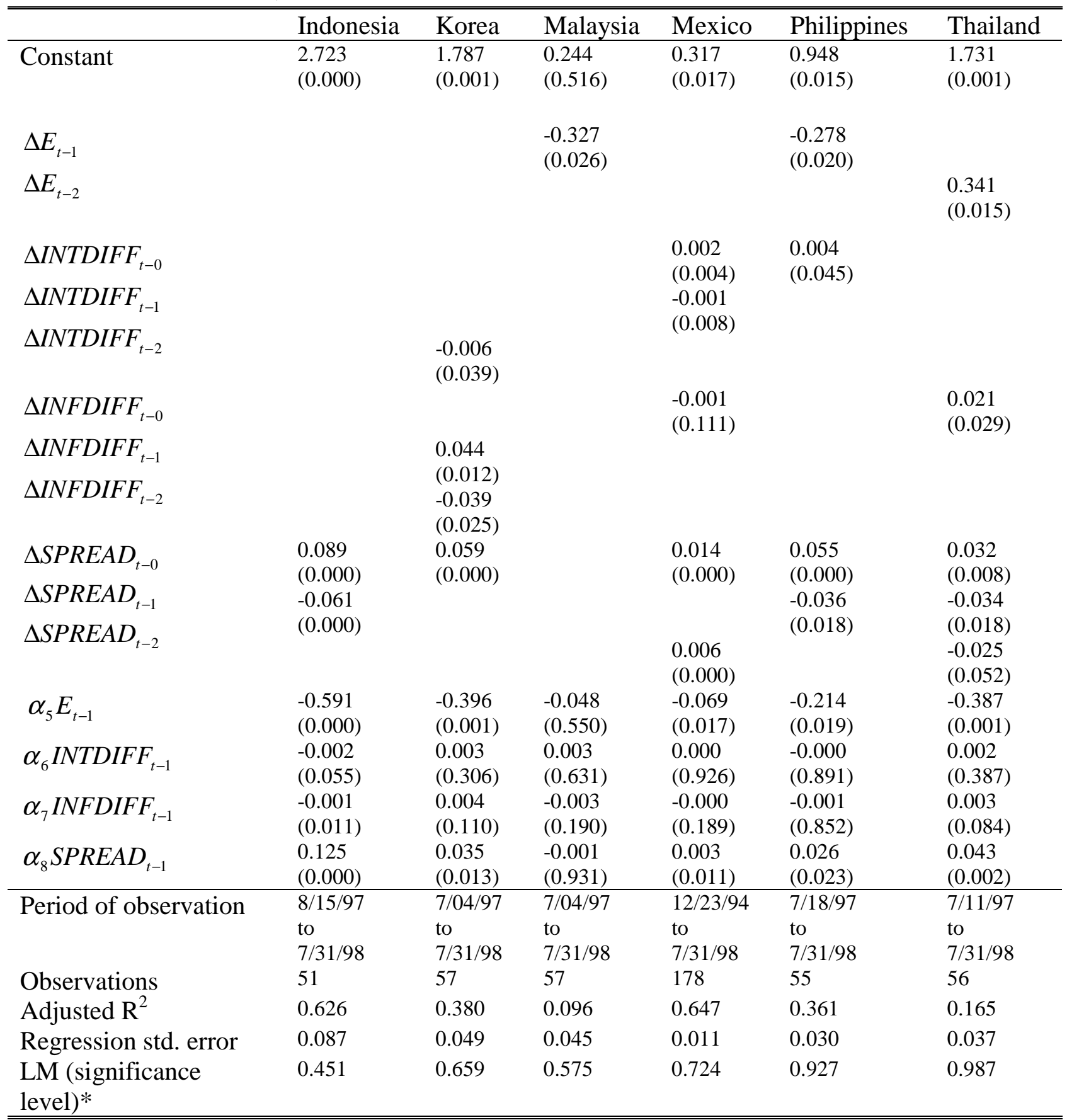

Note: Significance levels in parentheses.

* LM test for autocorrelation of errors; null hypothesis is that there is no autocorrelation. 
Table 11.5a. ECM estimation: benchmark model with stock return

Dependent variable: $\Delta E_{t}$

\begin{tabular}{|c|c|c|c|c|c|c|}
\hline & Indonesia & Korea & Malaysia & Mexico & Philippines & Thailand \\
\hline Constant & $\begin{array}{l}1.536 \\
(0.070)\end{array}$ & $\begin{array}{l}1.081 \\
(0.132)\end{array}$ & $\begin{array}{l}-0.180 \\
(0.724)\end{array}$ & $\begin{array}{l}0.251 \\
(0.072)\end{array}$ & $\begin{array}{l}0.718 \\
(0.119)\end{array}$ & $\begin{array}{l}1.899 \\
(0.004)\end{array}$ \\
\hline$\sum_{j=1}^{2} \alpha_{1 j} \Delta E_{t-j}$ & $\begin{array}{l}-0.006 \\
(0.287)\end{array}$ & $\begin{array}{l}-0.362 \\
(0.180)\end{array}$ & $\begin{array}{l}-0.622 \\
(0.087)\end{array}$ & $\begin{array}{l}0.023 \\
(0.267)\end{array}$ & $\begin{array}{l}-0.260 \\
(0.265)\end{array}$ & $\begin{array}{l}0.540 \\
(0.050)\end{array}$ \\
\hline$\sum_{j=0}^{2} \alpha_{2 j} \Delta I N T D I F F_{t-j}$ & $\begin{array}{l}0.003 \\
(0.395)\end{array}$ & $\begin{array}{l}-0.001 \\
(0.262)\end{array}$ & $\begin{array}{l}0.007 \\
(0.828)\end{array}$ & $\begin{array}{l}-0.001 \\
(0.006)\end{array}$ & $\begin{array}{l}0.002 \\
(0.319)\end{array}$ & $\begin{array}{l}0.006 \\
(0.522)\end{array}$ \\
\hline$\sum_{j=0}^{2} \alpha_{3 j} \Delta I N F D I F F_{t-j}$ & $\begin{array}{l}-0.006 \\
(0.091)\end{array}$ & $\begin{array}{l}0.025 \\
(0.102)\end{array}$ & $\begin{array}{l}0.014 \\
(0.654)\end{array}$ & $\begin{array}{l}-0.001 \\
(0.572)\end{array}$ & $\begin{array}{l}-0.021 \\
(0.698)\end{array}$ & $\begin{array}{l}0.017 \\
(0.725)\end{array}$ \\
\hline$\sum_{j=0}^{2} \alpha_{4 j} \Delta S P R E A D_{t-j}$ & $\begin{array}{l}0.048 \\
(0.000)\end{array}$ & $\begin{array}{l}0.043 \\
(0.129)\end{array}$ & $\begin{array}{l}-0.090 \\
(0.397)\end{array}$ & $\begin{array}{l}0.022 \\
(0.000)\end{array}$ & $\begin{array}{l}-0.031 \\
(0.034)\end{array}$ & $\begin{array}{l}-0.020 \\
(0.026)\end{array}$ \\
\hline$\sum_{j=0}^{2} \alpha_{5 j} \Delta S T K R E T_{t-j}$ & $\begin{array}{l}0.296 \\
(0.845)\end{array}$ & $\begin{array}{l}0.512 \\
(0.000)\end{array}$ & $\begin{array}{l}0.264 \\
(0.000)\end{array}$ & $\begin{array}{l}-0.059 \\
(0.393)\end{array}$ & $\begin{array}{l}0.264 \\
(0.123)\end{array}$ & $\begin{array}{l}-0.312 \\
(0.449)\end{array}$ \\
\hline$\alpha_{6} E_{t-1}$ & $\begin{array}{l}-0.324 \\
(0.077)\end{array}$ & $\begin{array}{l}-0.245 \\
(0.125)\end{array}$ & $\begin{array}{l}0.043 \\
(0.693)\end{array}$ & $\begin{array}{l}-0.055 \\
(0.068)\end{array}$ & $\begin{array}{l}-0.175 \\
(0.104)\end{array}$ & $\begin{array}{l}-0.434 \\
(0.004)\end{array}$ \\
\hline$\alpha_{7} I_{N T D I F F_{t-1}}$ & $\begin{array}{l}-0.005 \\
(0.021)\end{array}$ & $\begin{array}{l}0.001 \\
(0.852)\end{array}$ & $\begin{array}{l}-0.005 \\
(0.643)\end{array}$ & $\begin{array}{l}0.0001 \\
(0.921)\end{array}$ & $\begin{array}{l}0.003 \\
(0.987)\end{array}$ & $\begin{array}{l}0.004 \\
(0.222)\end{array}$ \\
\hline$\alpha_{8} I N F D I F F_{t-1}$ & $\begin{array}{l}-0.001 \\
(0.324)\end{array}$ & $\begin{array}{l}0.002 \\
(0.293)\end{array}$ & $\begin{array}{l}-0.001 \\
(0.761)\end{array}$ & $\begin{array}{l}-0.0003 \\
(0.055)\end{array}$ & $\begin{array}{l}0.001 \\
(0.752)\end{array}$ & $\begin{array}{l}0.006 \\
(0.045)\end{array}$ \\
\hline$\alpha_{9} S_{P R E A D_{t-1}}$ & $\begin{array}{l}0.089 \\
(0.007)\end{array}$ & $\begin{array}{l}0.030 \\
(0.082)\end{array}$ & $\begin{array}{l}-0.002 \\
(0.902)\end{array}$ & $\begin{array}{l}0.003 \\
(0.022)\end{array}$ & $\begin{array}{l}0.022 \\
(0.149)\end{array}$ & $\begin{array}{l}0.049 \\
(0.008)\end{array}$ \\
\hline$\alpha_{10}$ STKRET $_{t-1}$ & $\begin{array}{l}-0.290 \\
(0.724)\end{array}$ & $\begin{array}{l}-1.666 \\
(0.000)\end{array}$ & $\begin{array}{l}-1.148 \\
(0.001)\end{array}$ & $\begin{array}{l}-0.073 \\
(0.270)\end{array}$ & $\begin{array}{l}-0.459 \\
(0.079)\end{array}$ & $\begin{array}{l}0.081 \\
(0.723)\end{array}$ \\
\hline Period of observation & $\begin{array}{l}8 / 15 / 97 \\
\text { to } \\
7 / 31 / 98\end{array}$ & $\begin{array}{l}7 / 04 / 97 \\
\text { to } \\
7 / 31 / 98\end{array}$ & $\begin{array}{l}7 / 04 / 97 \\
\text { to } \\
7 / 31 / 98\end{array}$ & $\begin{array}{l}12 / 23 / 94 \\
\text { to } \\
7 / 31 / 98\end{array}$ & $\begin{array}{l}7 / 18 / 97 \\
\text { to } \\
7 / 31 / 98\end{array}$ & $\begin{array}{l}7 / 11 / 97 \\
\text { to } \\
7 / 31 / 98\end{array}$ \\
\hline Observations & 51 & 57 & 57 & 176 & 55 & 56 \\
\hline Adjusted $\mathrm{R}^{2}$ & 0.63 & 0.55 & 0.32 & 0.58 & 0.36 & 0.19 \\
\hline Regression std. error & 0.086 & 0.041 & 0.039 & 0.011 & 0.030 & 0.036 \\
\hline $\begin{array}{l}\text { LM (significance } \\
\text { level)* }\end{array}$ & 0.902 & 0.575 & 0.809 & 0.836 & 0.846 & 0.694 \\
\hline
\end{tabular}

Note: Significance levels in parentheses.

* LM test for autocorrelation of errors; null hypothesis is that there is no autocorrelation. 
Table 11.5b. ECM estimation: parsimonious benchmark model with stock return Dependent variable: $\Delta E_{t}$

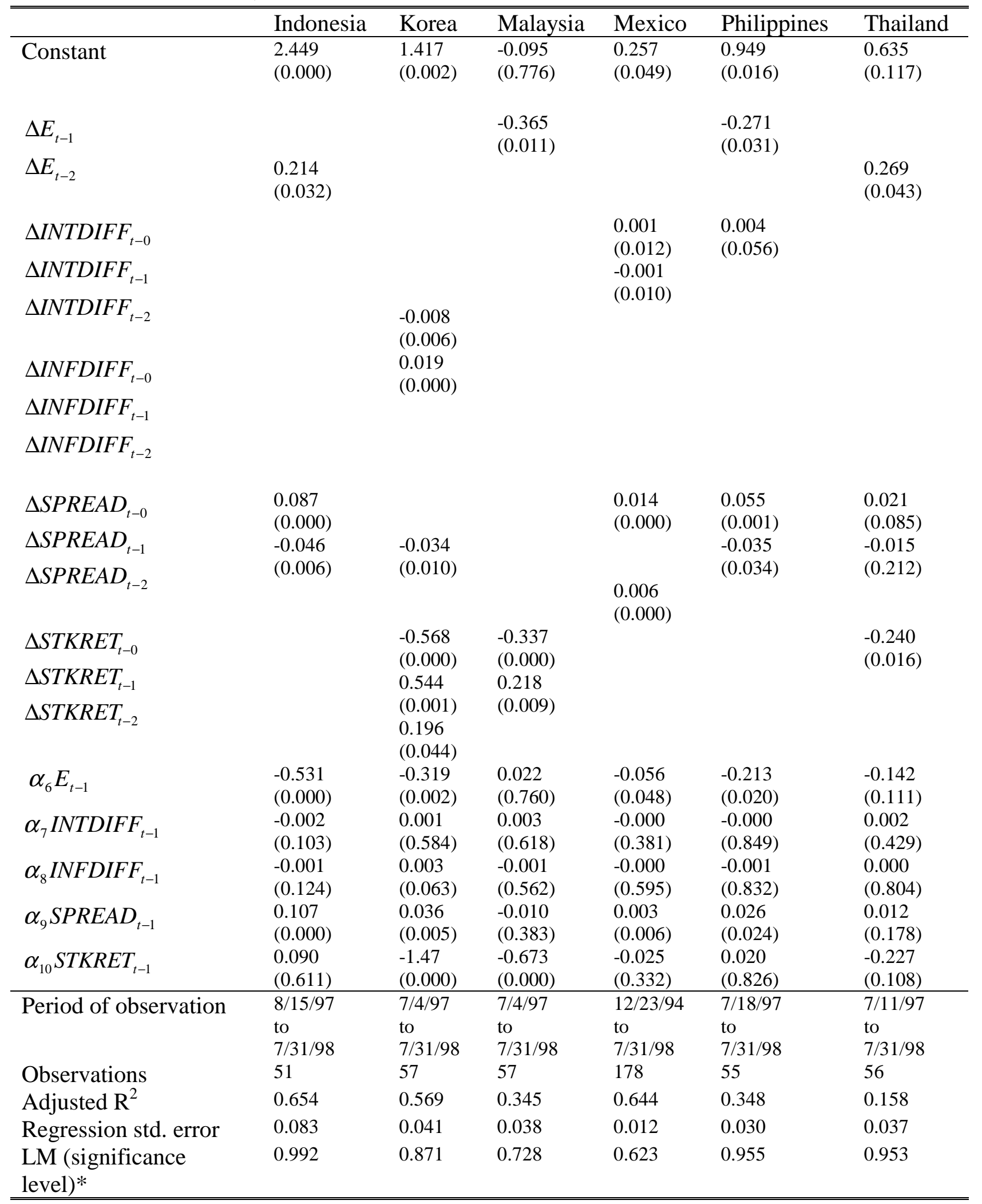


Note: Significance levels in parentheses.

* LM test for autocorrelation of errors; null hypothesis is that there is no autocorrelation. 
Table 11.6a. ECM estimation: benchmark model with stock return and bank stock return Dependent Variable: $\Delta E_{t}$

\begin{tabular}{|c|c|c|c|c|c|}
\hline & Indonesia & Korea & Malaysia & Mexico & Thailand \\
\hline Constant & $\begin{array}{l}1.295 \\
(0.182)\end{array}$ & $\begin{array}{l}1.484 \\
(0.055)\end{array}$ & $\begin{array}{l}-0.083 \\
(0.882)\end{array}$ & $\begin{array}{l}0.218 \\
(0.113)\end{array}$ & $\begin{array}{l}1.658 \\
(0.008)\end{array}$ \\
\hline$\sum_{j=1}^{2} \alpha_{1 j} \Delta E_{t-j}$ & $\begin{array}{l}-0.159 \\
(0.216)\end{array}$ & $\begin{array}{l}-0.242 \\
(0.373)\end{array}$ & $\begin{array}{l}-0.554 \\
(0.205)\end{array}$ & $\begin{array}{l}-0.001 \\
(0.086)\end{array}$ & $\begin{array}{l}0.183 \\
(0.604)\end{array}$ \\
\hline$\sum_{j=0}^{2} \alpha_{2 j} \Delta I N T D I F F_{t-j}$ & $\begin{array}{l}-0.001 \\
(0.671)\end{array}$ & $\begin{array}{l}-0.002 \\
(0.392)\end{array}$ & $\begin{array}{l}0.005 \\
(0.877)\end{array}$ & $\begin{array}{l}-0.001 \\
(0.011)\end{array}$ & $\begin{array}{l}0.010 \\
(0.181)\end{array}$ \\
\hline$\sum_{j=0}^{2} \alpha_{3 j} \Delta I N F D I F F_{t-j}$ & $\begin{array}{l}-0.006 \\
(0.589)\end{array}$ & $\begin{array}{l}0.020 \\
(0.015)\end{array}$ & $\begin{array}{l}0.010 \\
(0.832)\end{array}$ & $\begin{array}{l}-0.001 \\
(0.381)\end{array}$ & $\begin{array}{l}0.002 \\
(0.179)\end{array}$ \\
\hline$\sum_{j=0}^{2} \alpha_{4 j} \Delta S P R E A D_{t-j}$ & $\begin{array}{l}0.041 \\
(0.000)\end{array}$ & $\begin{array}{l}0.013 \\
(0.233)\end{array}$ & $\begin{array}{l}-0.099 \\
(0.358)\end{array}$ & $\begin{array}{l}0.020 \\
(0.000)\end{array}$ & $\begin{array}{l}0.003 \\
(0.232)\end{array}$ \\
\hline$\sum_{j=0}^{2} \alpha_{5 j} \Delta S T K R E T_{t-j}$ & $\begin{array}{l}-0.102 \\
(0.740)\end{array}$ & $\begin{array}{l}0.351 \\
(0.002)\end{array}$ & $\begin{array}{l}0.213 \\
(0.038)\end{array}$ & $\begin{array}{l}0.012 \\
(0.782)\end{array}$ & $\begin{array}{l}-0.548 \\
(0.192)\end{array}$ \\
\hline$\sum_{j=0}^{2} \alpha_{6 j} \Delta(B S T K R E T-S T K R E T)_{t-j}$ & $\begin{array}{l}-1.223 \\
(0.410)\end{array}$ & $\begin{array}{l}0.256 \\
(0.010)\end{array}$ & $\begin{array}{l}-0.192 \\
(0.515)\end{array}$ & $\begin{array}{l}-0.153 \\
(0.022)\end{array}$ & $\begin{array}{l}0.820 \\
(0.015)\end{array}$ \\
\hline$\alpha_{7} E_{t-1}$ & $\begin{array}{l}-0.277 \\
(0.193)\end{array}$ & $\begin{array}{l}-0.334 \\
(0.053)\end{array}$ & $\begin{array}{l}0.021 \\
(0.862)\end{array}$ & $\begin{array}{l}-0.048 \\
(0.109)\end{array}$ & $\begin{array}{l}-0.369 \\
(0.009)\end{array}$ \\
\hline$\alpha_{8} I N T D I F F_{t-1}$ & $\begin{array}{l}-0.005 \\
(0.090)\end{array}$ & $\begin{array}{l}0.001 \\
(0.784)\end{array}$ & $\begin{array}{l}-0.002 \\
(0.862)\end{array}$ & $\begin{array}{l}-0.000 \\
(0.710)\end{array}$ & $\begin{array}{l}0.001 \\
(0.691)\end{array}$ \\
\hline$\alpha_{9} I N F D I F F_{t-1}$ & $\begin{array}{l}-0.001 \\
(0.311)\end{array}$ & $\begin{array}{l}0.004 \\
(0.105)\end{array}$ & $\begin{array}{l}-0.001 \\
(0.725)\end{array}$ & $\begin{array}{l}-0.000 \\
(0.112)\end{array}$ & $\begin{array}{l}0.006 \\
(0.018)\end{array}$ \\
\hline$\alpha_{10} S_{P R E A D_{t-1}}$ & $\begin{array}{l}0.086 \\
(0.042)\end{array}$ & $\begin{array}{l}0.036 \\
(0.042)\end{array}$ & $\begin{array}{l}-0.002 \\
(0.901)\end{array}$ & $\begin{array}{l}0.003 \\
(0.010)\end{array}$ & $\begin{array}{l}0.030 \\
(0.097)\end{array}$ \\
\hline$\alpha_{11}$ STKRET $_{t-1}$ & $\begin{array}{l}-0.583 \\
(0.513)\end{array}$ & $\begin{array}{l}-1.284 \\
(0.004)\end{array}$ & $\begin{array}{l}-0.839 \\
(0.068)\end{array}$ & $\begin{array}{l}-0.085 \\
(0.197)\end{array}$ & $\begin{array}{l}0.460 \\
(0.061)\end{array}$ \\
\hline$\alpha_{12}(B S T K R E T-S T K R E T)_{t-1}$ & $\begin{array}{l}-0.406 \\
(0.811)\end{array}$ & $\begin{array}{l}-0.622 \\
(0.050)\end{array}$ & $\begin{array}{l}-0.362 \\
(0.470)\end{array}$ & $\begin{array}{l}0.042 \\
(0.433)\end{array}$ & $\begin{array}{l}-1.32 \\
(0.013)\end{array}$ \\
\hline Period of observation & $\begin{array}{l}8 / 15 / 97 \\
\text { to } \\
7 / 31 / 98\end{array}$ & $\begin{array}{l}7 / 4 / 97 \\
\text { to } \\
7 / 31 / 98\end{array}$ & $\begin{array}{l}7 / 4 / 97 \\
\text { to } \\
7 / 31 / 98\end{array}$ & $\begin{array}{l}12 / 23 / 94 \\
\text { to } \\
7 / 31 / 98\end{array}$ & $\begin{array}{l}7 / 11 / 97 \\
\text { to } \\
7 / 31 / 98\end{array}$ \\
\hline Observations & 51 & 57 & 57 & 176 & 56 \\
\hline Adjusted $\mathrm{R}^{2}$ & 0.622 & 0.641 & 0.272 & 0.592 & 0.341 \\
\hline Regression std. error & 0.087 & 0.037 & 0.040 & 0.011 & 0.033 \\
\hline LM (significance level)* & 0.846 & 0.749 & 0.868 & 0.847 & 0.568 \\
\hline
\end{tabular}

Note: Significance levels in parentheses.

* LM test for autocorrelation of errors; null hypothesis is that there is no autocorrelation. 
Table 11.6b. ECM estimation: parsimonious benchmark model with stock return and bank stock return

Dependent Variable: $\Delta E_{t}$

\begin{tabular}{|c|c|c|c|c|c|}
\hline & Indonesia & Korea & Malaysia & Mexico & Thailand \\
\hline Constant & $\begin{array}{l}1.396 \\
(0.006)\end{array}$ & $\begin{array}{l}1.797 \\
(0.000)\end{array}$ & $\begin{array}{l}0.046 \\
(0.888)\end{array}$ & $\begin{array}{l}0.229 \\
(0.072)\end{array}$ & $\begin{array}{l}1.193 \\
(0.005)\end{array}$ \\
\hline $\begin{array}{l}\Delta E_{t-1} \\
\Delta E_{t-2}\end{array}$ & $\begin{array}{l}-0.453 \\
(0.000)\end{array}$ & & $\begin{array}{l}-0.416 \\
(0.005)\end{array}$ & & \\
\hline $\begin{array}{l}\Delta I N T D I F F_{t-0} \\
\Delta I N T D I F F_{t-1} \\
\Delta I N T D I F F_{t-2}\end{array}$ & & $\begin{array}{l}-0.006 \\
(0.023)\end{array}$ & & $\begin{array}{l}0.001 \\
(0.003) \\
-0.001 \\
(0.006)\end{array}$ & $\begin{array}{l}0.010 \\
(0.010)\end{array}$ \\
\hline $\begin{array}{l}\Delta I N F D I F F_{t-0} \\
\Delta I N F D I F F_{t-1}\end{array}$ & $\begin{array}{l}-0.004 \\
(0.043)\end{array}$ & $\begin{array}{l}0.014 \\
(0.000)\end{array}$ & & & $\begin{array}{l}0.019 \\
(0.111)\end{array}$ \\
\hline$\Delta I N F D I F F_{t-2}$ & & & & & $\begin{array}{l}-0.024 \\
(0.021)\end{array}$ \\
\hline $\begin{array}{l}\triangle S P R E A D_{t-0} \\
\triangle S P R E A D_{t-1}\end{array}$ & $\begin{array}{l}0.085 \\
(0.000)\end{array}$ & $\begin{array}{l}0.025 \\
(0.031)\end{array}$ & & $\begin{array}{l}0.014 \\
(0.000)\end{array}$ & $\begin{array}{l}0.032 \\
(0.006)\end{array}$ \\
\hline$\triangle S P R E A D_{t-2}$ & & & & $\begin{array}{l}0.006 \\
(0.000)\end{array}$ & \\
\hline$\Delta S T K R E T_{t-0}$ & & $\begin{array}{l}-0.445 \\
(0.000)\end{array}$ & $\begin{array}{l}-0.232 \\
(0.013)\end{array}$ & & \\
\hline $\begin{array}{l}\Delta S T K R E T_{t-1} \\
\Delta S T K R E T_{t-2}\end{array}$ & & $\begin{array}{l}0.228 \\
(0.018)\end{array}$ & & & $\begin{array}{l}-0.206 \\
(0.029)\end{array}$ \\
\hline $\begin{array}{l}\Delta(B S T K R E T-S T K R E T)_{t-0} \\
\Delta(B S T K R E T-S T K R E T)_{t-1} \\
\Delta(B S T K R E T-S T K R E T)_{t-2}\end{array}$ & $\begin{array}{l}-0.770 \\
(0.006)\end{array}$ & $\begin{array}{l}0.415 \\
(0.000)\end{array}$ & $\begin{array}{l}-0.317 \\
(0.037)\end{array}$ & $\begin{array}{l}-0.071 \\
(0.002)\end{array}$ & $\begin{array}{l}-0.297 \\
(0.016) \\
0.633 \\
(0.000)\end{array}$ \\
\hline$\alpha_{7} E_{t-1}$ & $\begin{array}{l}-0.299 \\
(0.007)\end{array}$ & $\begin{array}{l}-0.405 \\
(0.000)\end{array}$ & $\begin{array}{l}-0.009 \\
(0.896)\end{array}$ & $\begin{array}{l}-0.050 \\
(0.070)\end{array}$ & $\begin{array}{l}-0.259 \\
(0.006)\end{array}$ \\
\hline$\alpha_{8} I N T D I F F_{t-1}$ & $\begin{array}{l}-0.003 \\
(0.014)\end{array}$ & $\begin{array}{l}0.004 \\
(0.073)\end{array}$ & $\begin{array}{l}0.006 \\
(0.290)\end{array}$ & $\begin{array}{l}-0.000 \\
(0.238)\end{array}$ & $\begin{array}{l}0.001 \\
(0.740)\end{array}$ \\
\hline$\alpha_{9} I_{N F D I F F_{t-1}}$ & $\begin{array}{l}-0.001 \\
(0.044)\end{array}$ & $\begin{array}{l}0.002 \\
(0.117)\end{array}$ & $\begin{array}{l}-0.002 \\
(0.225)\end{array}$ & $\begin{array}{l}-0.000 \\
(0.630)\end{array}$ & $\begin{array}{l}0.004 \\
(0.048)\end{array}$ \\
\hline$\alpha_{10} S P R E A D_{t-1}$ & $\begin{array}{l}0.078 \\
(0.000)\end{array}$ & $\begin{array}{l}0.039 \\
(0.000)\end{array}$ & $\begin{array}{l}-0.009 \\
(0.441)\end{array}$ & $\begin{array}{l}0.003 \\
(0.004)\end{array}$ & $\begin{array}{l}0.014 \\
(0.190)\end{array}$ \\
\hline$\alpha_{11} S_{T K R E T_{t-1}}$ & $\begin{array}{l}0.175 \\
(0.355)\end{array}$ & $\begin{array}{l}-0.921 \\
(0.000)\end{array}$ & $\begin{array}{l}-0.177 \\
(0.257)\end{array}$ & $\begin{array}{l}-0.021 \\
(0.425)\end{array}$ & $\begin{array}{l}0.440 \\
(0.003)\end{array}$ \\
\hline$\alpha_{12}(B S T K R E T-S T K R E T)_{t-1}$ & $\begin{array}{l}-1.157 \\
(0.011)\end{array}$ & $\begin{array}{l}-0.472 \\
(0.002)\end{array}$ & $\begin{array}{l}-0.591 \\
(0.005)\end{array}$ & $\begin{array}{l}0.052 \\
(0.124)\end{array}$ & $\begin{array}{l}-1.130 \\
(0.000)\end{array}$ \\
\hline
\end{tabular}




\begin{tabular}{llllll}
\hline Period of observation & $8 / 15 / 97$ & $7 / 4 / 97$ & $7 / 4 / 97$ & $12 / 23 / 94$ & $7 / 11 / 97$ \\
& to & to & to & to & to \\
& $7 / 31 / 98$ & $7 / 31 / 98$ & $7 / 31 / 98$ & $7 / 31 / 98$ & $7 / 31 / 98$ \\
Observations & 51 & 57 & 57 & 178 & 56 \\
Adjusted R & 0.660 & 0.664 & 0.345 & 0.661 & 0.415 \\
Regression std. error & 0.083 & 0.036 & 0.038 & 0.011 & 0.031 \\
LM (significance level)* & 0.827 & 0.589 & 0.159 & 0.468 & 0.546 \\
\hline \hline
\end{tabular}

Note: Significance levels in parentheses.

* LM test for autocorrelation of errors; null hypothesis is that there is no autocorrelation. 


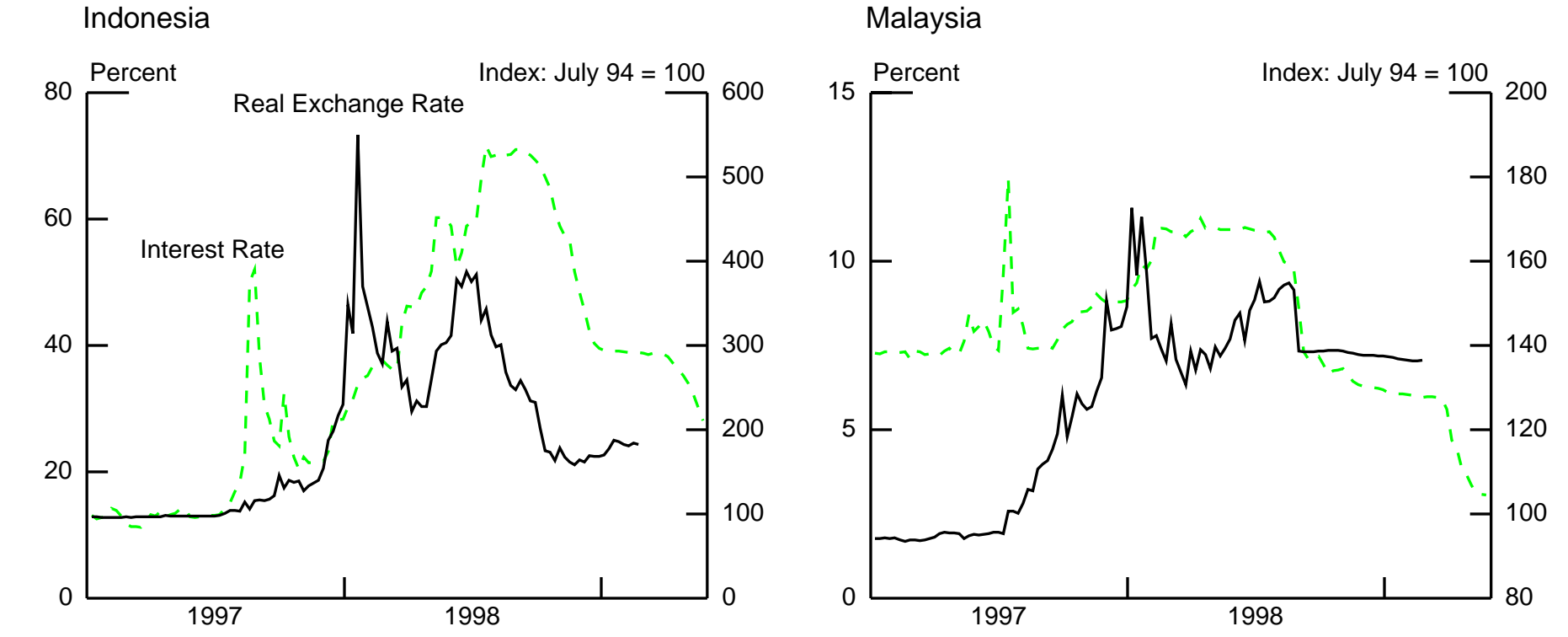

Malaysia

\section{Korea}

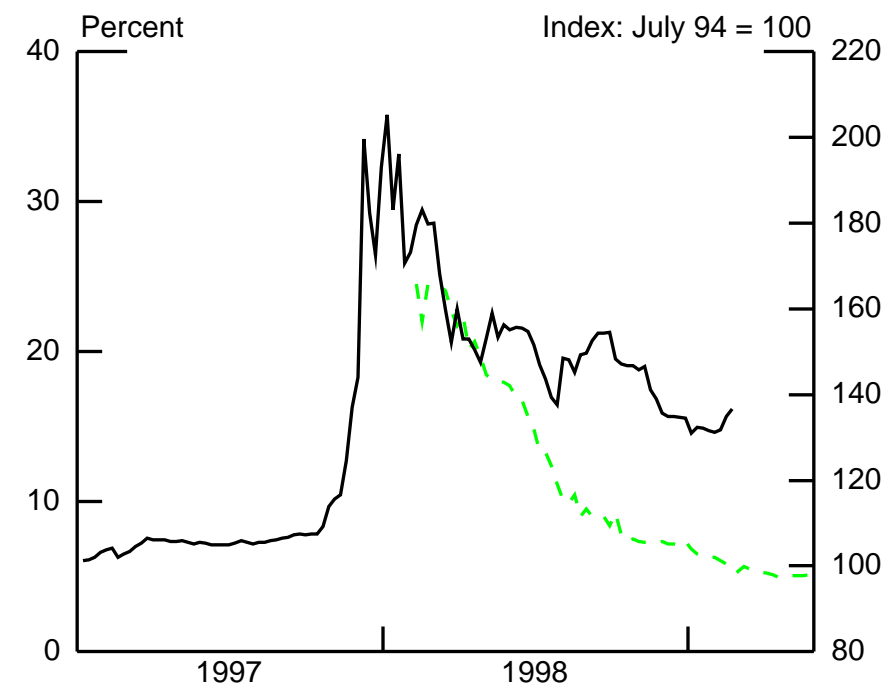

Philippines

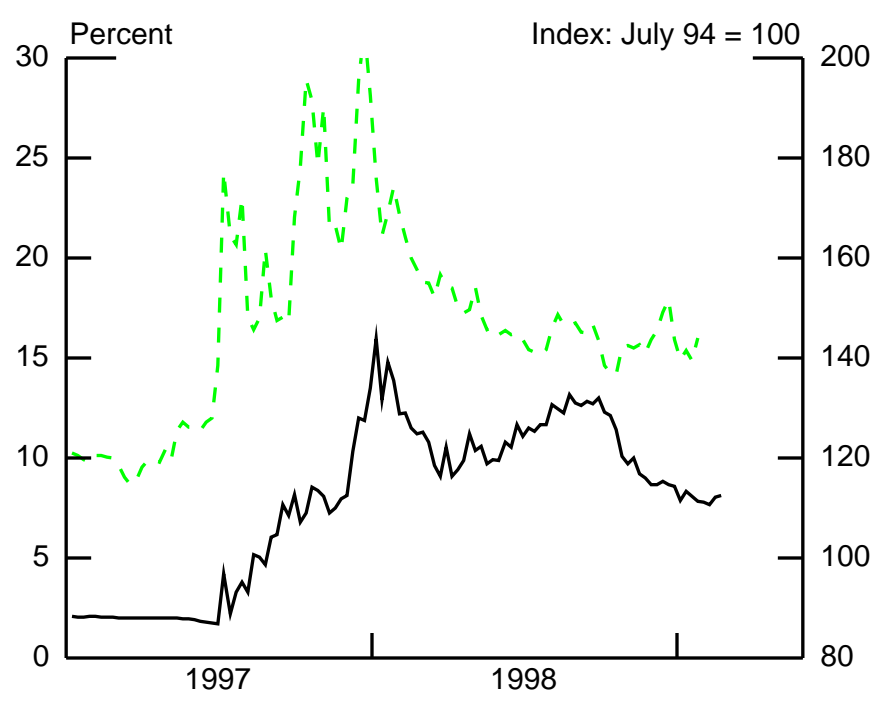

Thailand

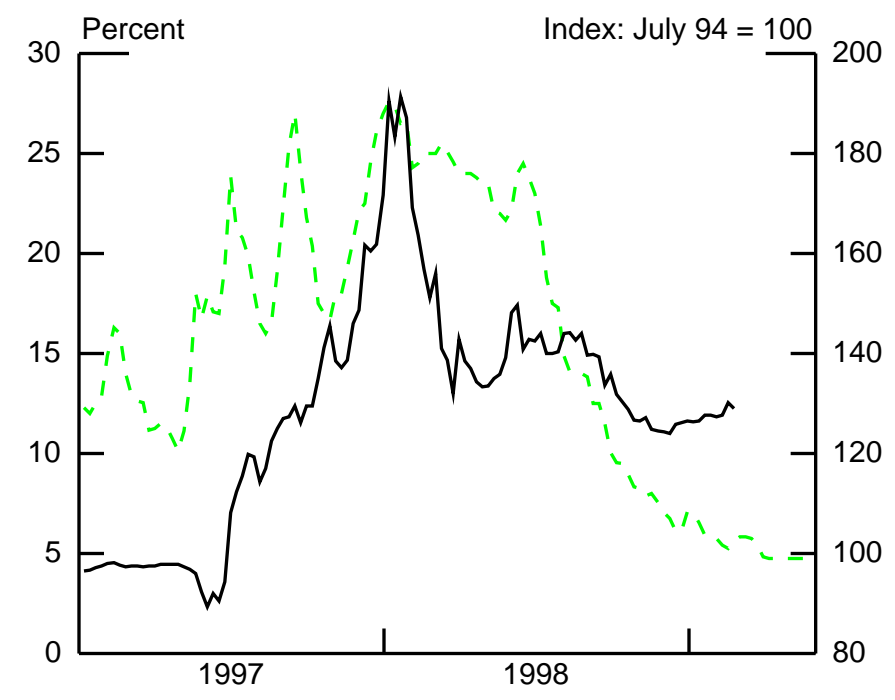

Mexico

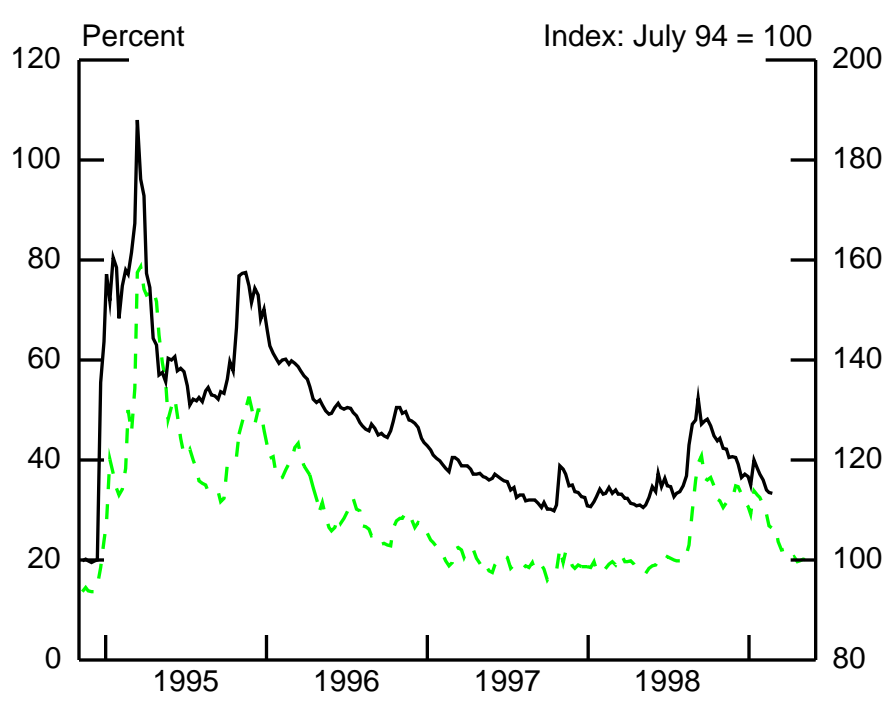

Figure 11.1. Interest rates and real exchange rates. Exchange rates are local currency per dollar. 
Indonesia

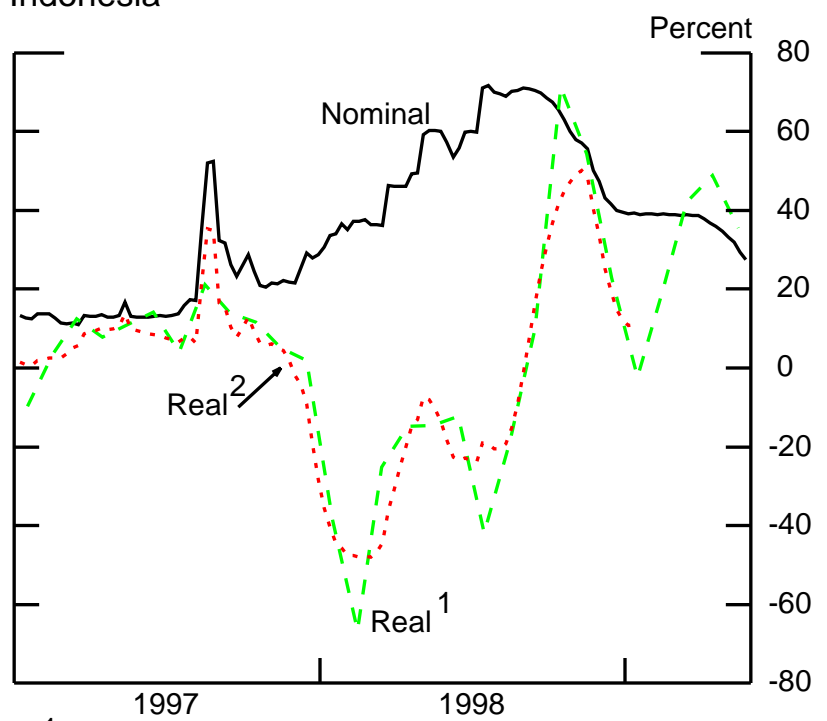

1 Deflated by current month's inflation rate.

2 Deflated by centered 13-week moving average of inflation rate. Korea

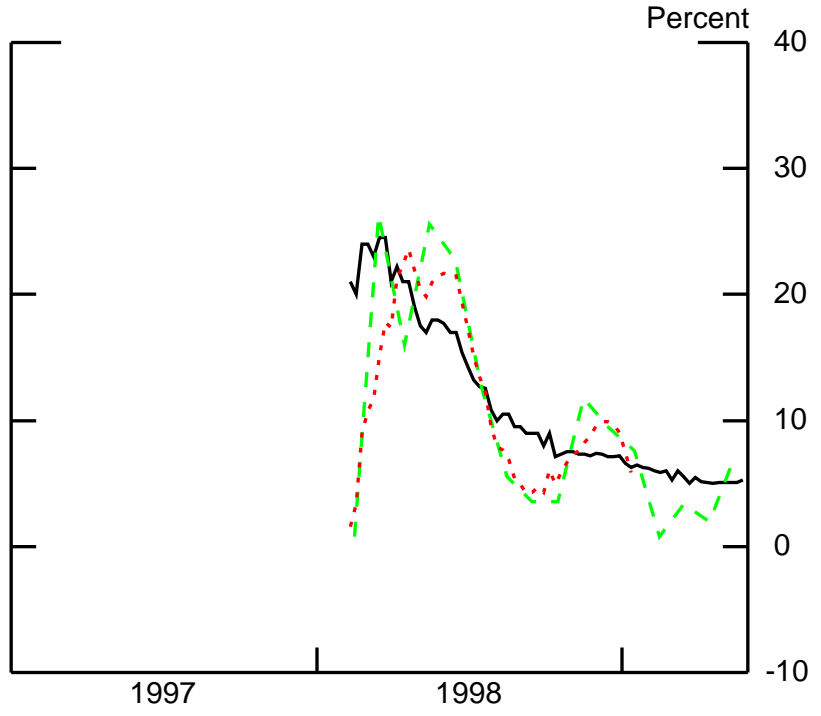

Philippines

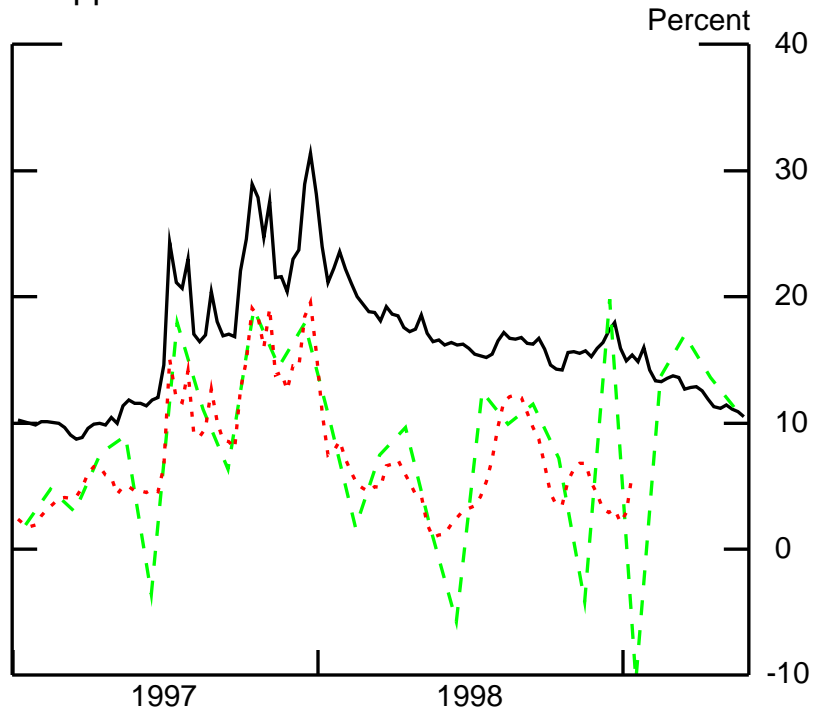

Malaysia

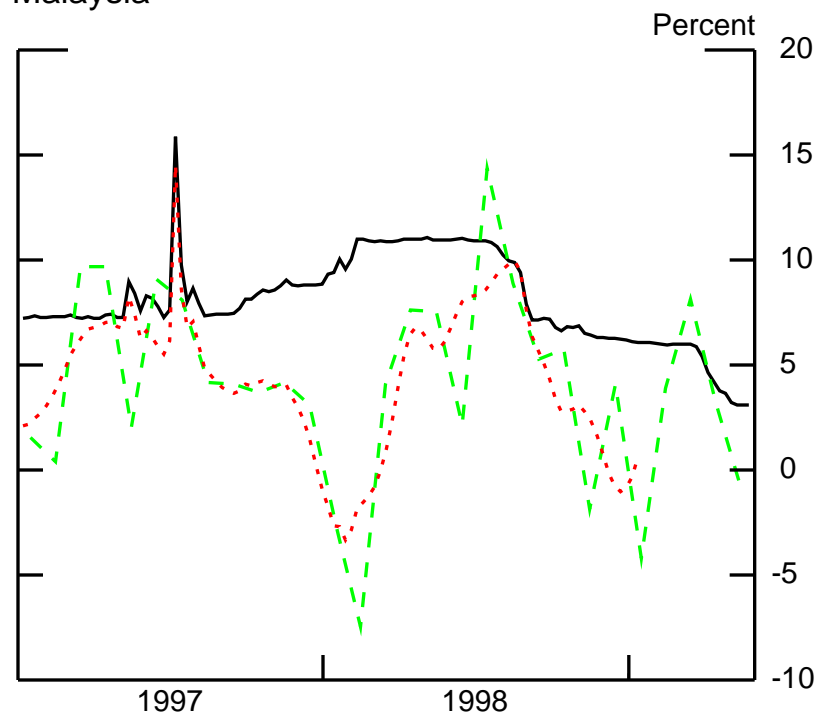

Thailand

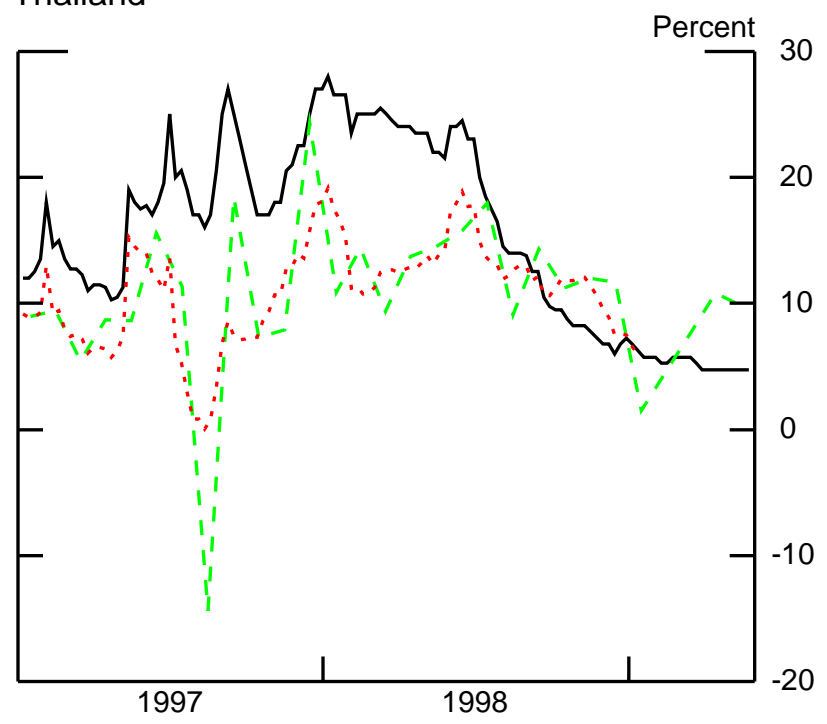

Mexico

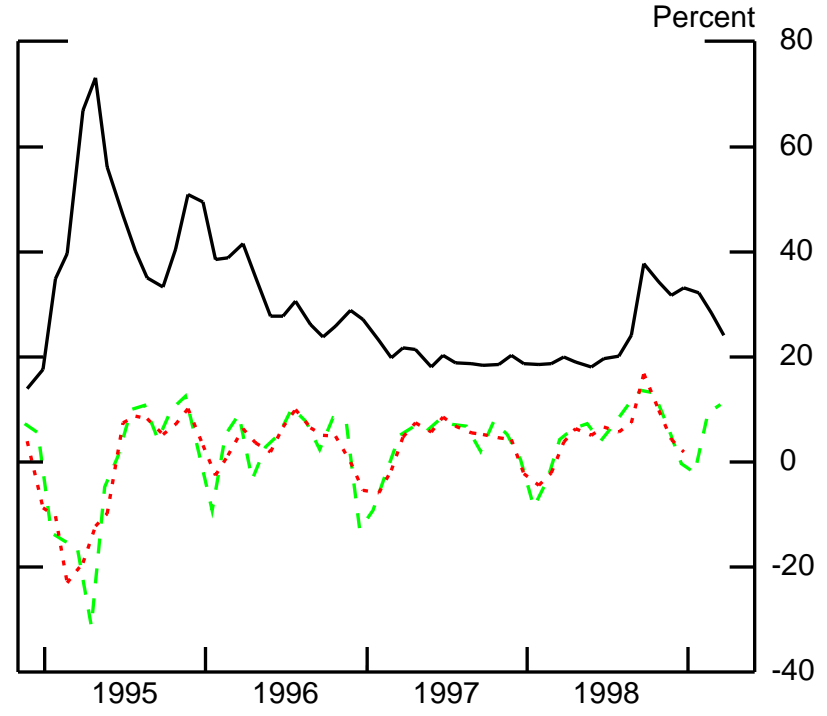

Figure 11.2. Movements in short term interest rates. 


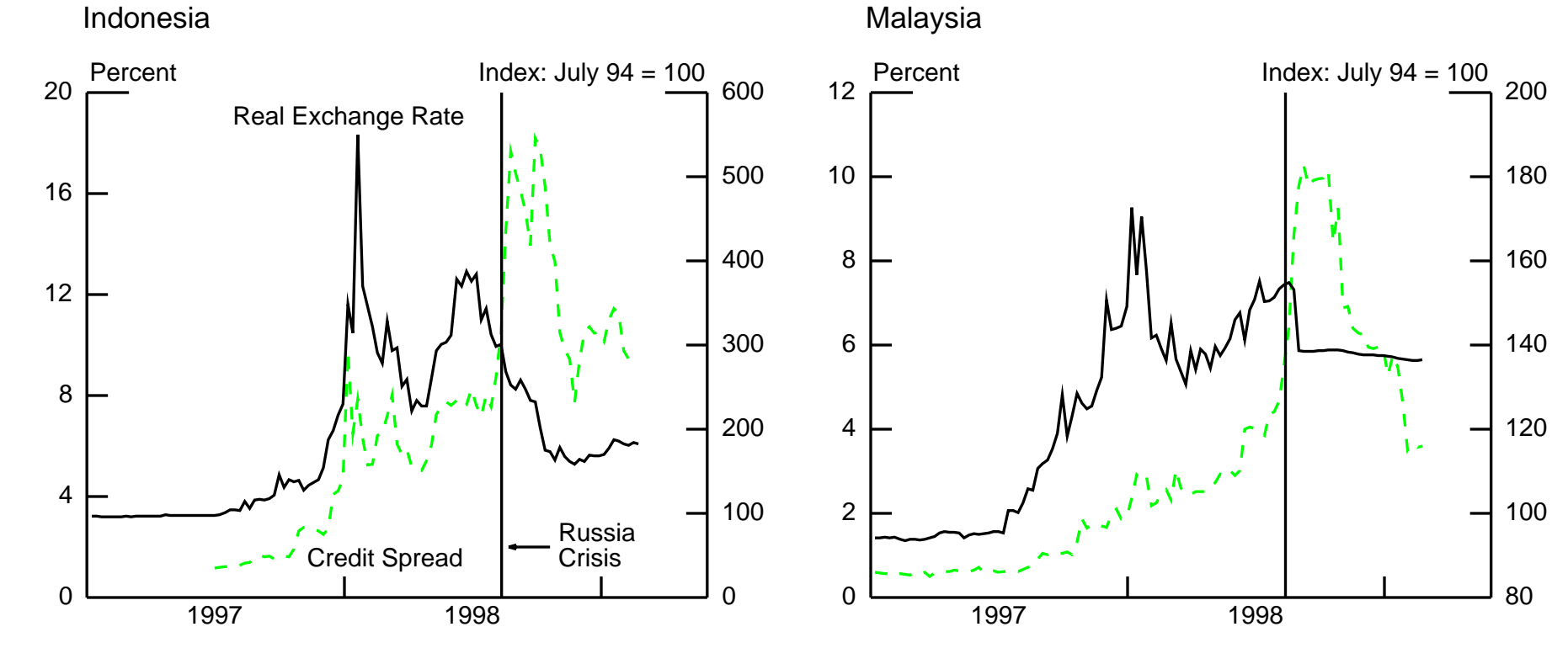

Malaysia

Korea

Thailand
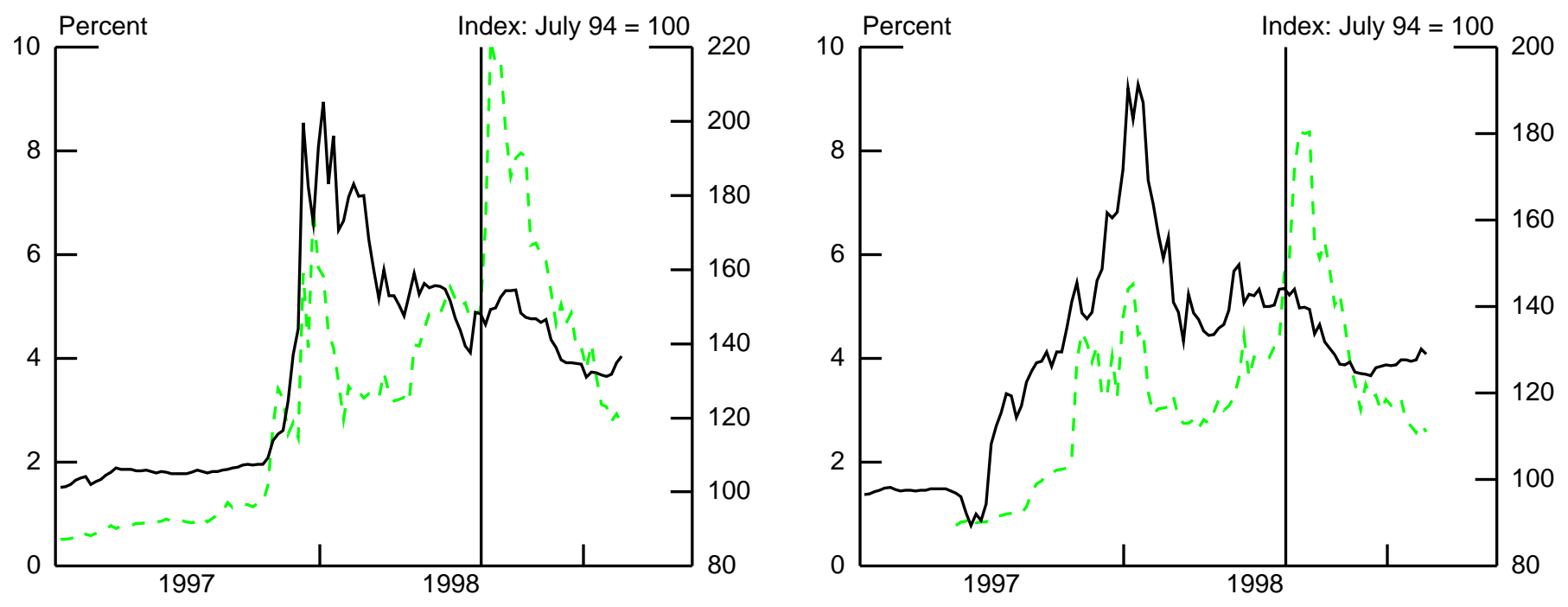

Philippines

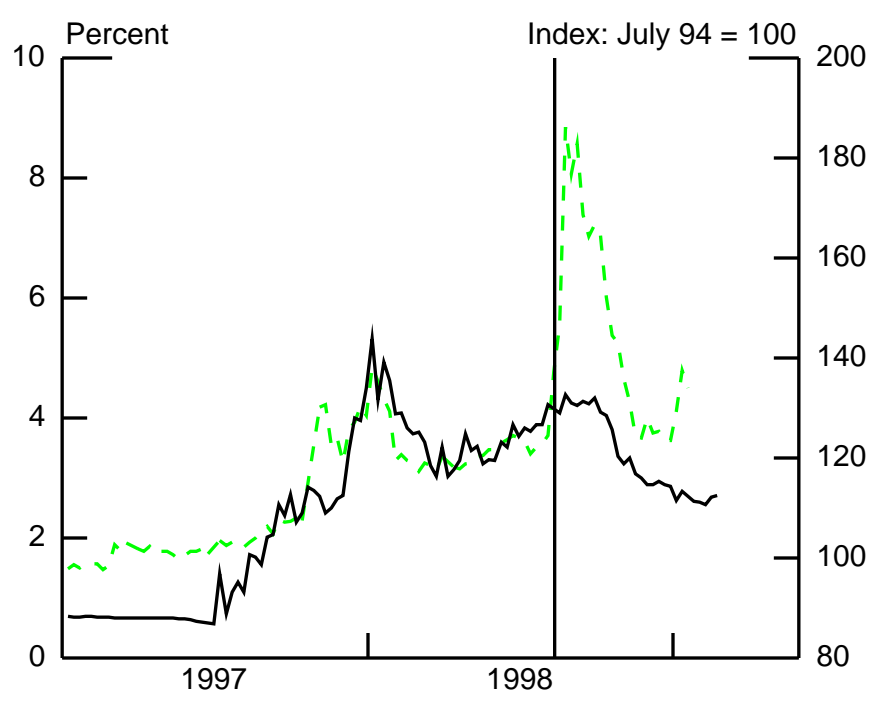

Mexico

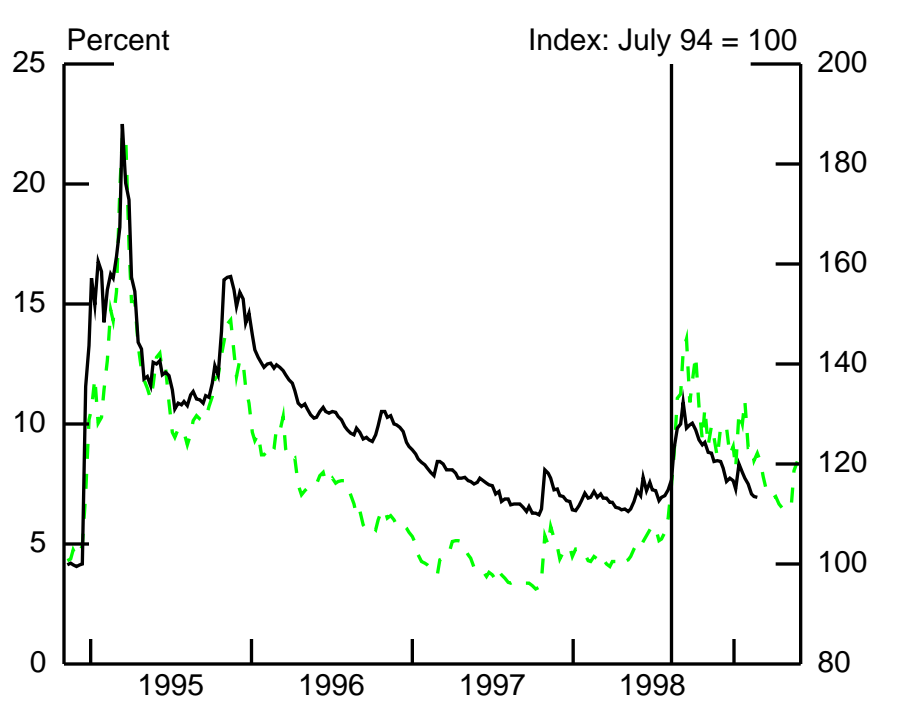

Figure 11.3. International credit spreads and real exchange rates. Exchange rates are local currency per dollar. 

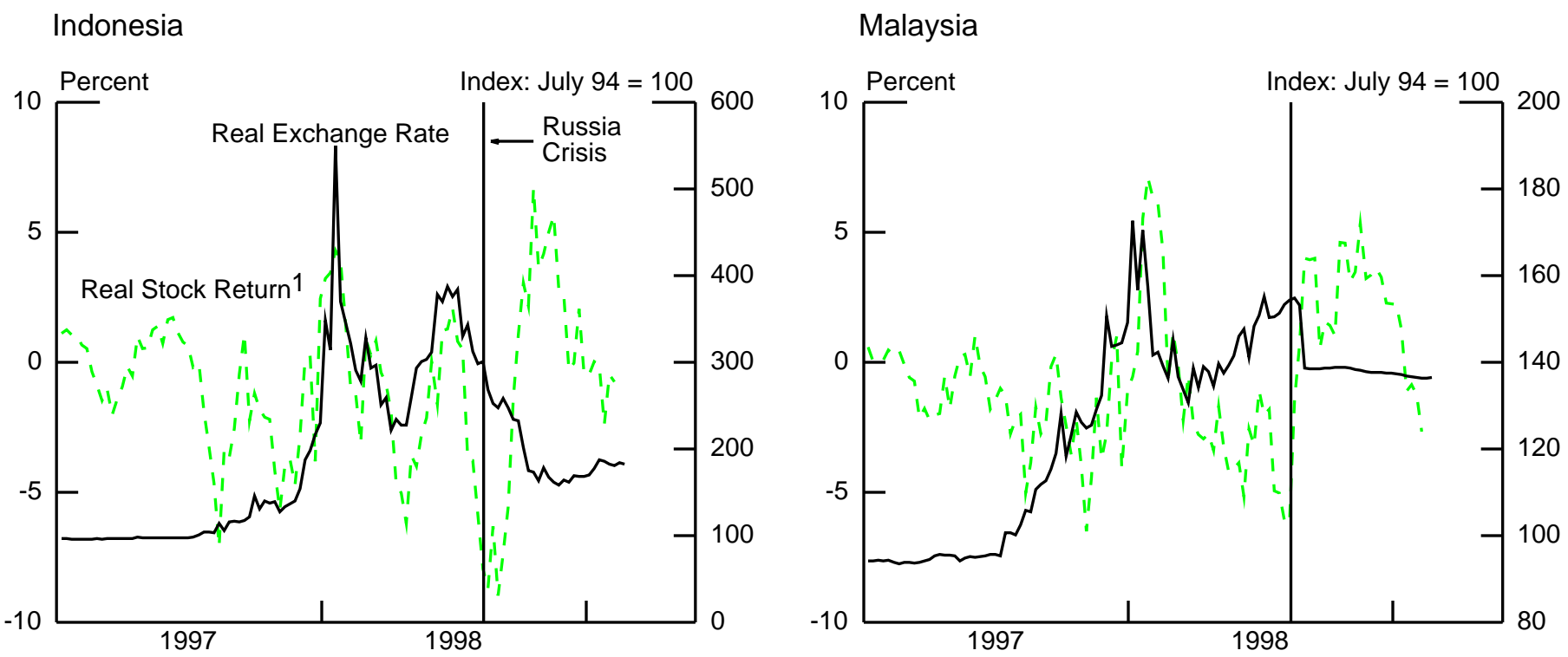

15 -week centered moving average of CPI-deflated stock return.

\section{Korea}

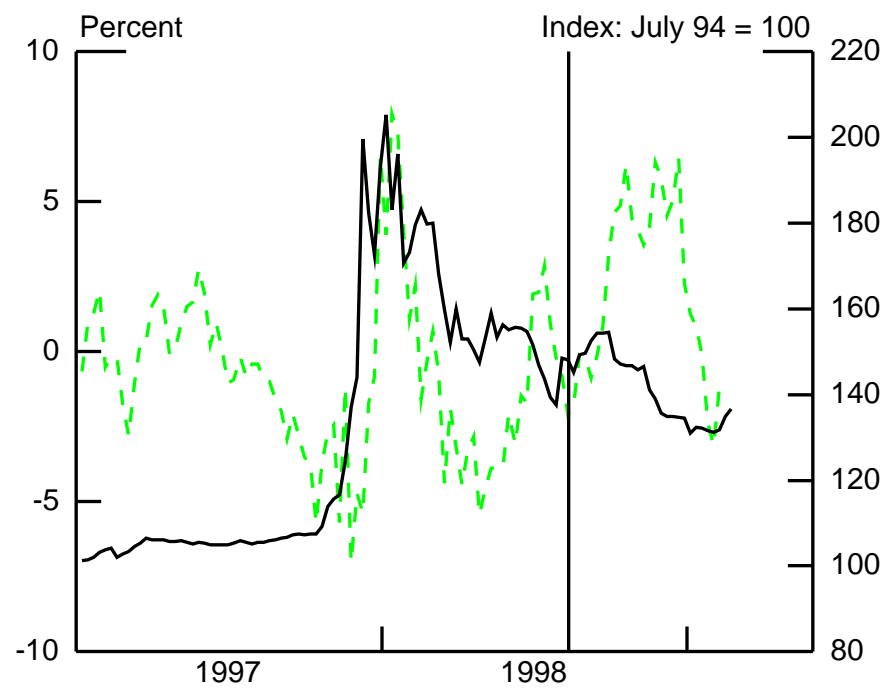

Philippines

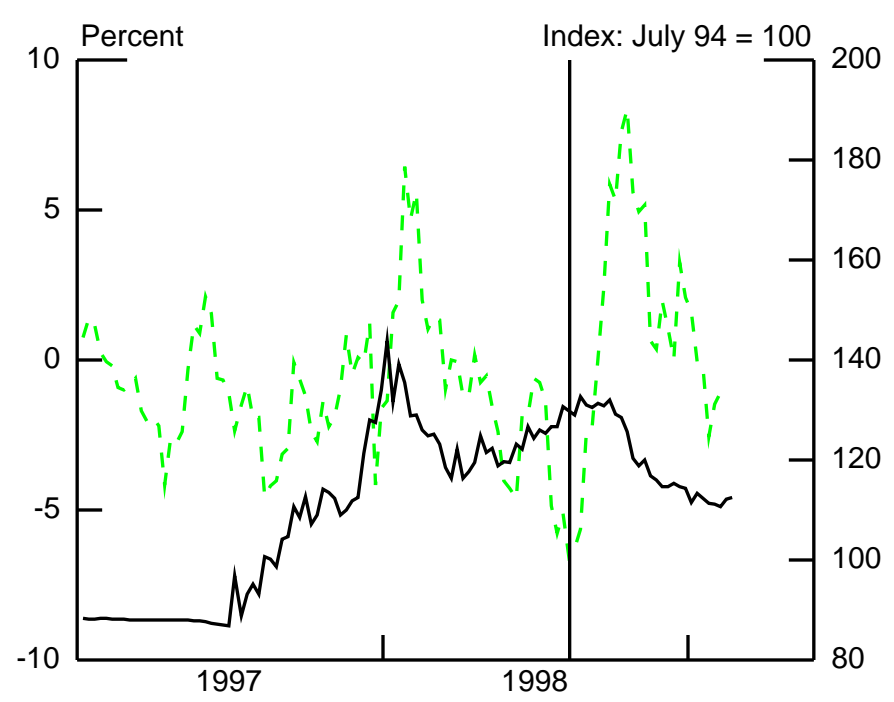

Thailand

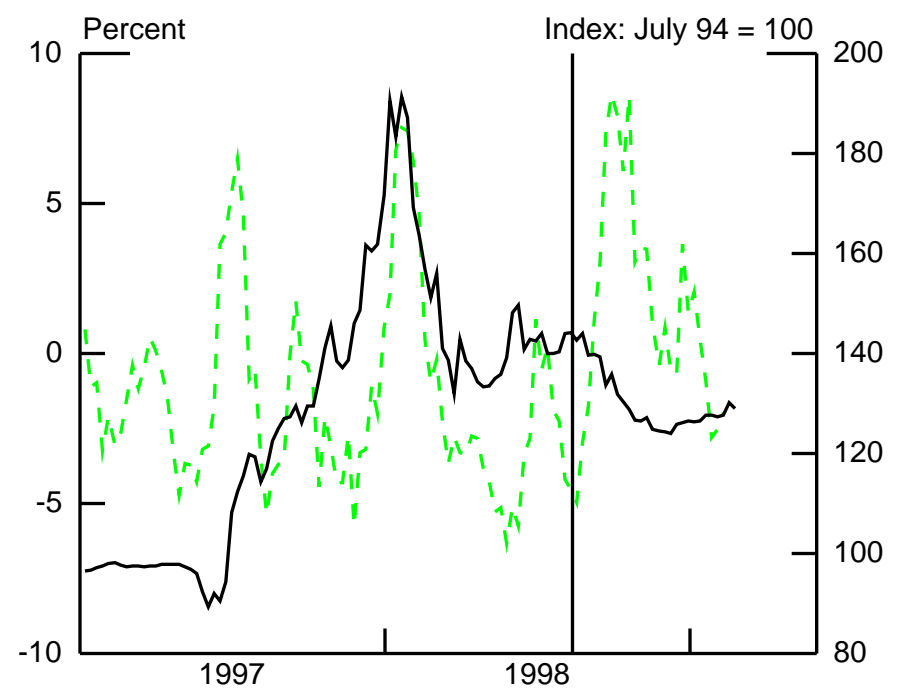

Mexico

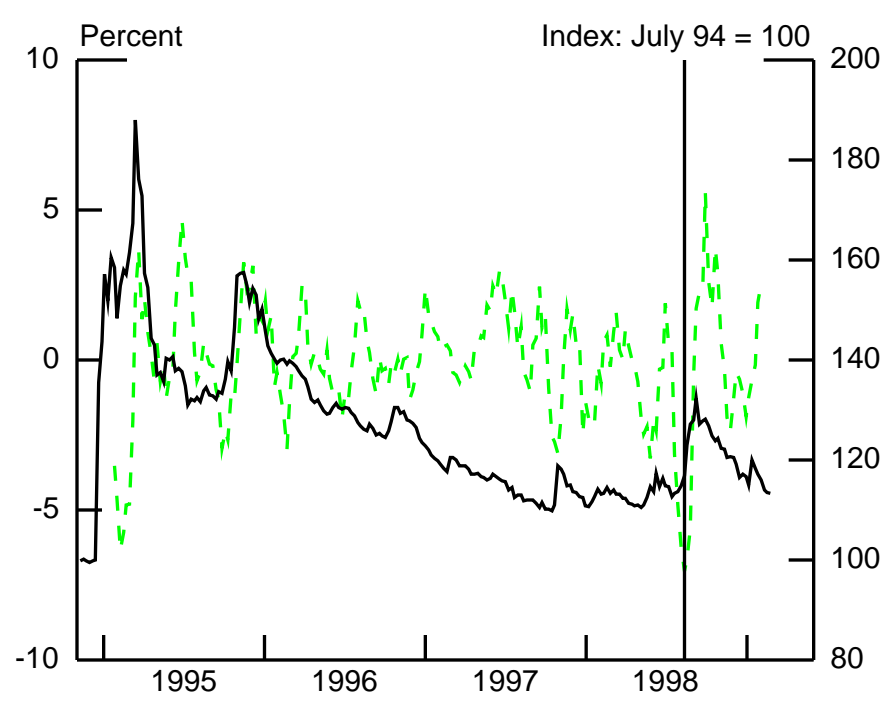

Figure 11.4. Real stock returns and real exchange rates. Exchange rates are local currency per dollar. 


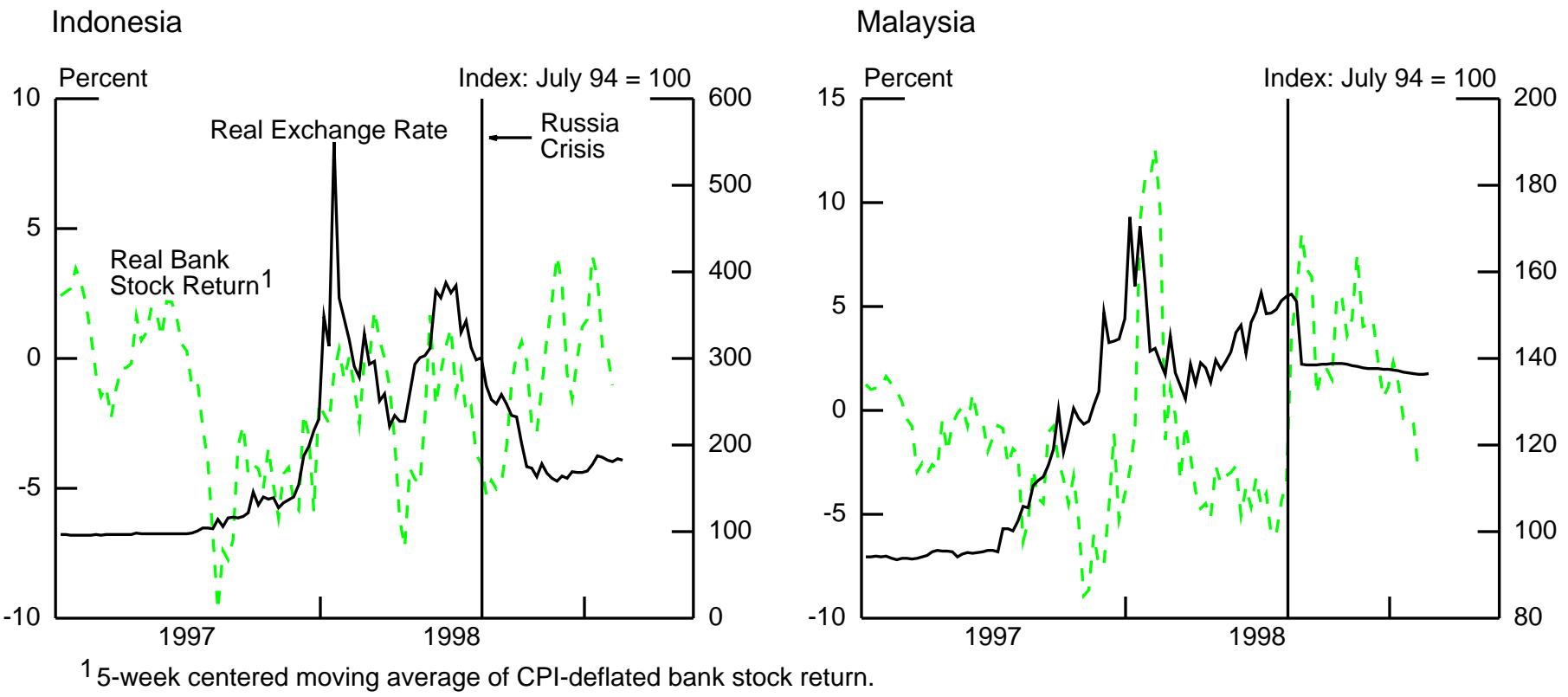

\section{Korea}

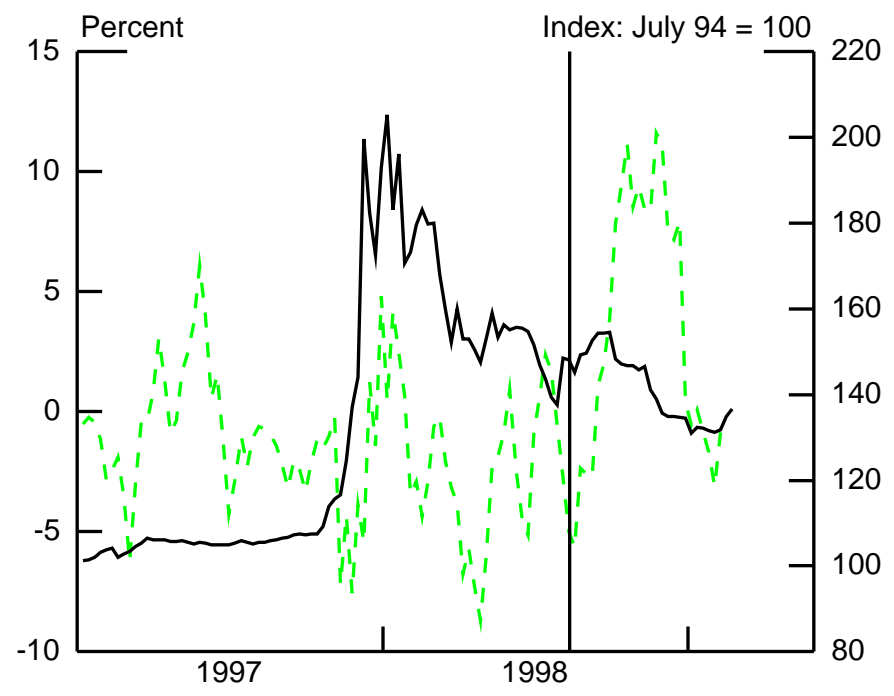

Mexico

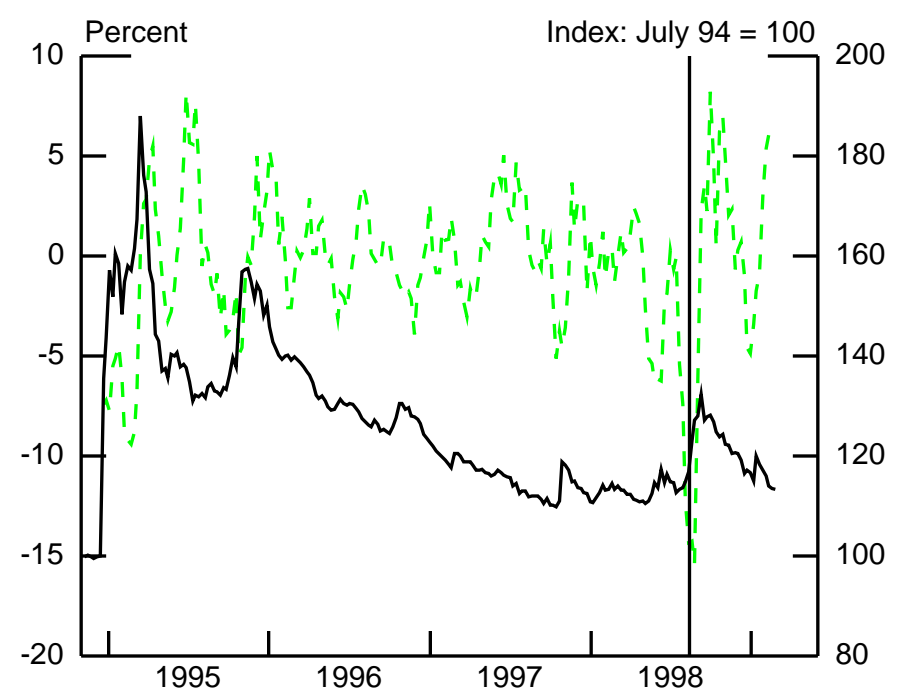

Thailand

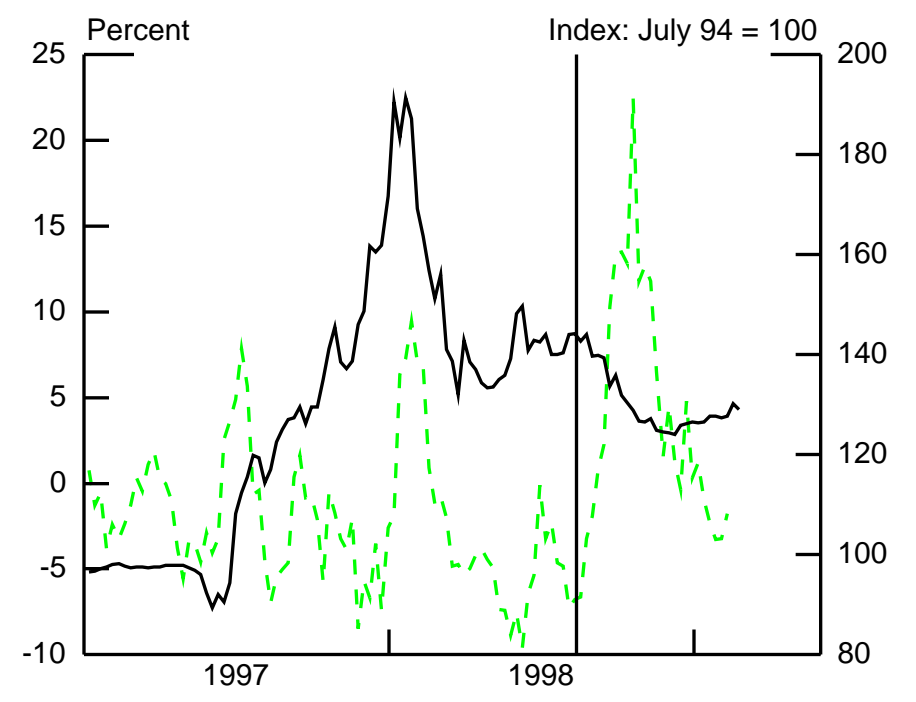

Figure 11.5. Real bank stock returns and real exchange rates. Exchange rates are local currency per dollar. 